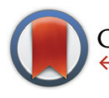

CrossMark \&lick for updates

Cite this: Dalton Trans., 2015, 44 14937

Received 22nd June 2015, Accepted 24th July 2015 DOI: $10.1039 / c 5 d t 02358 k$ www.rsc.org/dalton

\section{Chiral probe development for circularly polarised luminescence: comparative study of structural factors determining the degree of induced CPL with four heptacoordinate europium(III) complexes $\dagger$}

\author{
Emily R. Neil, Mark A. Fox, Robert Pal, Lars-Olof Pålsson, Benjamin A. O'Sullivan and \\ David Parker*
}

\begin{abstract}
A series of bright, europium(III) complexes has been prepared based on an achiral heptadentate triazacyclononane ligand bearing two strongly absorbing, coordinated aralkynyl pyridyl moieties. The binding of chiral carboxylates, including $\alpha$-hydroxy acids such as lactate and mandelate, has been monitored by emission spectroscopy and is signalled by the switching on of strong circularly polarised emission. In each case, an $R$-chiral carboxylate gave rise to emission typical of a $\Delta$ complex, most clearly shown in the form of the $\Delta J=4$ transition manifold around $700 \mathrm{~nm}$. Variations in the sign and magnitude of the CPL allow the enantiomeric purity and absolute configuration of the acid to be assessed in a sample. Analysis of the relative energies of the parent aqua complexes and their stereoisomeric adducts has been aided by lifetime measurements and density functional theory calculations.
\end{abstract}

\section{Introduction}

Amongst the family of chiroptical spectroscopy techniques, circularly polarised luminescence (CPL) spectroscopy has several unique advantages. ${ }^{1-3}$ Inherently, it is much more sensitive than electronic circular dichroism (ECD), the analogous ground-state technique that relies upon differential absorption of left and right-handed circularly polarised light. Arguably the most significant difference is that with the CPL technique, selective excitation and detection of the emissive complex can be achieved, giving rise to a unique signal that is free from background interference. In analogous systems relying on ECD detection, the background from the medium or matrix, notably in biological systems, often contributes extensively to the optical signal that is observed.

The chiroptical behaviour of strongly emissive lanthanide(III) complexes has dominated CPL probe development, and time-gating techniques allow the long-lived signal from the lanthanide(III) centre to be observed selectively. ${ }^{4-6}$ The emissive lanthanide excited state can be perturbed in a variety of different ways, including changes in local solvent structure,

Department of Chemistry, Durham University, South Road, Durham, DH1 3LE, UK. E-mail:david.parker@dur.ac.uk

$\dagger$ Electronic supplementary information (ESI) available. See DOI: 10.1039/ c5dt02358k sensitivity to energy transfer and static or dynamic charge transfer quenching processes. ${ }^{7}$ In particular, changes in the ligand field can occur arising from reversible binding to the metal or the ligand..$^{8-10}$ The latter modulation is of particular use to signal the presence of chiral species in solution.

The emission spectra of $\mathrm{Ln}^{\mathrm{III}}$ complexes are sensitive to changes in the coordination environment that determine the ligand field. Such behaviour can be considered to arise from perturbation of the electric susceptibility tensor and its anisotropy that defines the optical behaviour of the lanthanide complex in solution. At the same time, the magnetic susceptibility tensor, characterising the behaviour of a given lanthanide(III) complex in a magnetic field, serves to rationalise the magnetic properties of the complex, i.e. its susceptibility; the anisotropy of this tensor is of paramount importance in rationalising NMR behaviour, primarily determining the paramagnetic shift and EPR characteristics. ${ }^{11-13}$

In europium emission spectra, the oscillator strength of the magnetic-dipole allowed $\Delta J=1$ transition $(c a .590 \mathrm{~nm})$ is generally considered to be independent of the ligand environment. The $\Delta J=2$ and $\Delta J=4$ transitions (ca. 615 and $700 \mathrm{~nm}$ respectively) are electric-dipole (ED)-allowed and are hypersensitive to ligand perturbation. To a first approximation, their intensities are proportional to the square of the ligand dipolar polarisabilities. A ligand polarisation model has been advo- 

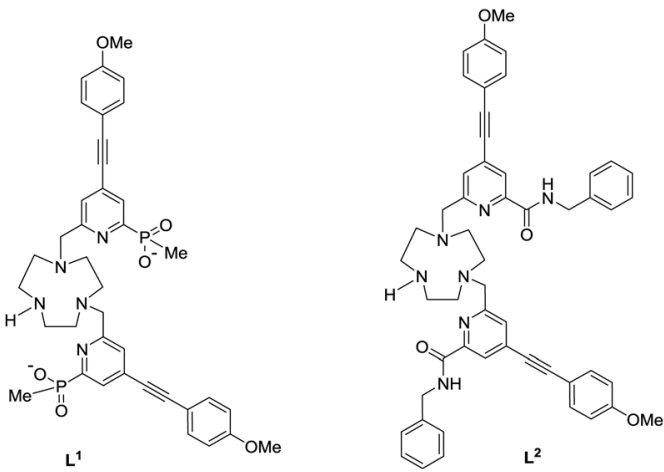

cated $^{14}$ to develop our understanding of lanthanide optical emission behaviour, in which electric-quadrupole-allowed transitions (e.g. ${ }^{5} \mathrm{D}_{0}$ to ${ }^{7} \mathrm{~F}_{2 / 4}$ ) gain ED strength via a quadrupole (on the $\mathrm{Ln}^{3+}$ ion)-induced dipole (ligand) coupling mechanism. The induced dipoles on the ligands are created by direct coupling to the ED components of the radiation field. Thus, 4f-4f ED strength has been directly linked to ligand dipolar polarisabilities and to the anisotropies of these polarisabilities. ${ }^{15}$

For Eu(III) complexes, perturbation of the ligand field has a particularly significant impact on the emission profile. Thus, variation of the axial donor in square antiprismatic complexes has a major effect on the relative intensity of the ${ }^{7} F_{2} \leftarrow{ }^{5} D_{0}$ transition, ${ }^{16}$ and has been exploited in the signalling of reversible anion binding to the metal centre in aqueous media. Several practical examples of anion sensing have emerged, including the assay of citrate, lactate and bicarbonate in biofluids. ${ }^{17-20}$ More recently, reversible binding to certain acute phase proteins in serum, e.g. $\alpha_{1}$-AGP, has been reported, in which a glutamate side chain carboxylate that is close to the main hydrophobic binding pocket binds to the Eu centre. ${ }^{21,22}$ In each case, the interaction is signalled by modulation of the total emission spectrum, and can be calibrated to measure changes in the intensity ratio of two or more emission bands. However, such analyses are not normally sensitive to chiral aspects that arise from stereoselective interactions. For this issue to be addressed, chiroptical spectroscopic methods need to be employed.

A racemic mixture of $\mathrm{Ln}^{\mathrm{III}}$ complexes in an achiral environment does not exhibit CPL. However, following addition of a chiral agent a net CPL signal may be obtained. For the cases where a chiral anion or protein can bind reversibly to the metal centre of a racemic complex, the formation of diastereoisomeric complexes of differing relative stability will lead to an induced CPL signal whose relative intensity will be dependent on the selectivity of binding and the conformational rigidity of the complex on the emission timescale. The intrinsic 'brightness' of the observed species is also a key practical aspect, as the acquisition of the total emission $\left(I_{\mathrm{L}}+I_{\mathrm{R}}\right)$ and the CPL $\left(I_{\mathrm{L}}-\right.$ $I_{\mathrm{R}}$ ) signals should be as rapid as possible. Owing to the relative simplicity of Eu(III) total emission spectra, arising from the
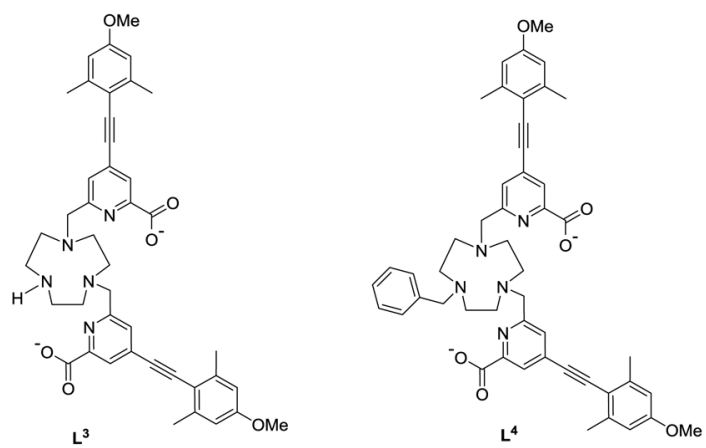

absence of degeneracy of the ${ }^{5} \mathrm{D}_{0}$ emissive state, these changes are best observed with europium complexes.

Recently, a new series of very bright Eu(III) complexes has been introduced, in which 1,4,7-triazacyclononane $\left(9-\mathrm{N}_{3}\right)$ serves as the core ligand structure with various substituted pyridyl-alkynylaryl groups acting as the sensitising chromophore. ${ }^{23-27}$ In particular, complexes that are coordinatively unsaturated based on heptadentate ligands have been prepared $^{28}$ and can bind reversibly to anions in aqueous media. In this work, we compare and contrast the behaviour of the $\mathrm{Eu}(\mathrm{III})$ complexes of the ligands $\mathrm{L}^{1}-\mathrm{L}^{4}$, and trace the key ligand structural features that distinguish their ability to serve as effective chiral probes for CPL.

The diphosphinate ligand $\mathrm{L}^{1}$ has been reported in preliminary work, ${ }^{28}$ and is compared to the carboxylate and amide analogues, $\mathrm{L}^{2-4}$. The ligand $\mathrm{L}^{4}$ has an $N$-benzyl substituent that increases the steric demand at the metal centre. The minor variations in chromophore constitution across the series resulting from substitution of the remote aryl ring, were considered not to change the nature of the binding of the chiral anions at the metal centre. Particular attention has been paid to the interaction of enantiopure chiral carboxylic acids and $\alpha$-hydroxy-acids (e.g. lactate and mandelate). Acetate and lactate anions have been shown by NMR and X-ray studies to bind to the metal centre, forming 4 or 5 ring chelates, in related work with $\mathrm{Eu}(\mathrm{III})$ complexes of less sterically demanding heptadentate ligands based on $12-\mathrm{N}_{4} \cdot{ }^{29,30}$

\section{Results and discussion}

\section{Ligand and complex synthesis and characterisation}

The syntheses of the achiral ligands $\mathrm{L}^{2-4}$ used established methodology, involving either a controlled alkylation strategy or the use of mono-BOC protected 1,4,7-triazacyclononane, (Schemes 1 and 2). Base hydrolysis of methyl(4-iodo-6-hydroxymethyl) picolinate, ${ }^{31}$ followed by amide coupling afforded the benzylamide, 2. A Sonogashira coupling reaction with 4-methoxyphenylalkyne, catalysed by $\mathrm{Pd}(\mathrm{dppf}) \mathrm{Cl}_{2}$, gave the alcohol $\mathbf{3}$, which was converted into the corresponding mesylate, 4, under standard conditions ( $\left.\mathrm{MsCl} / \mathrm{THF}, \mathrm{Et}_{3} \mathrm{~N}, 0^{\circ} \mathrm{C}\right)$. Alkylation 

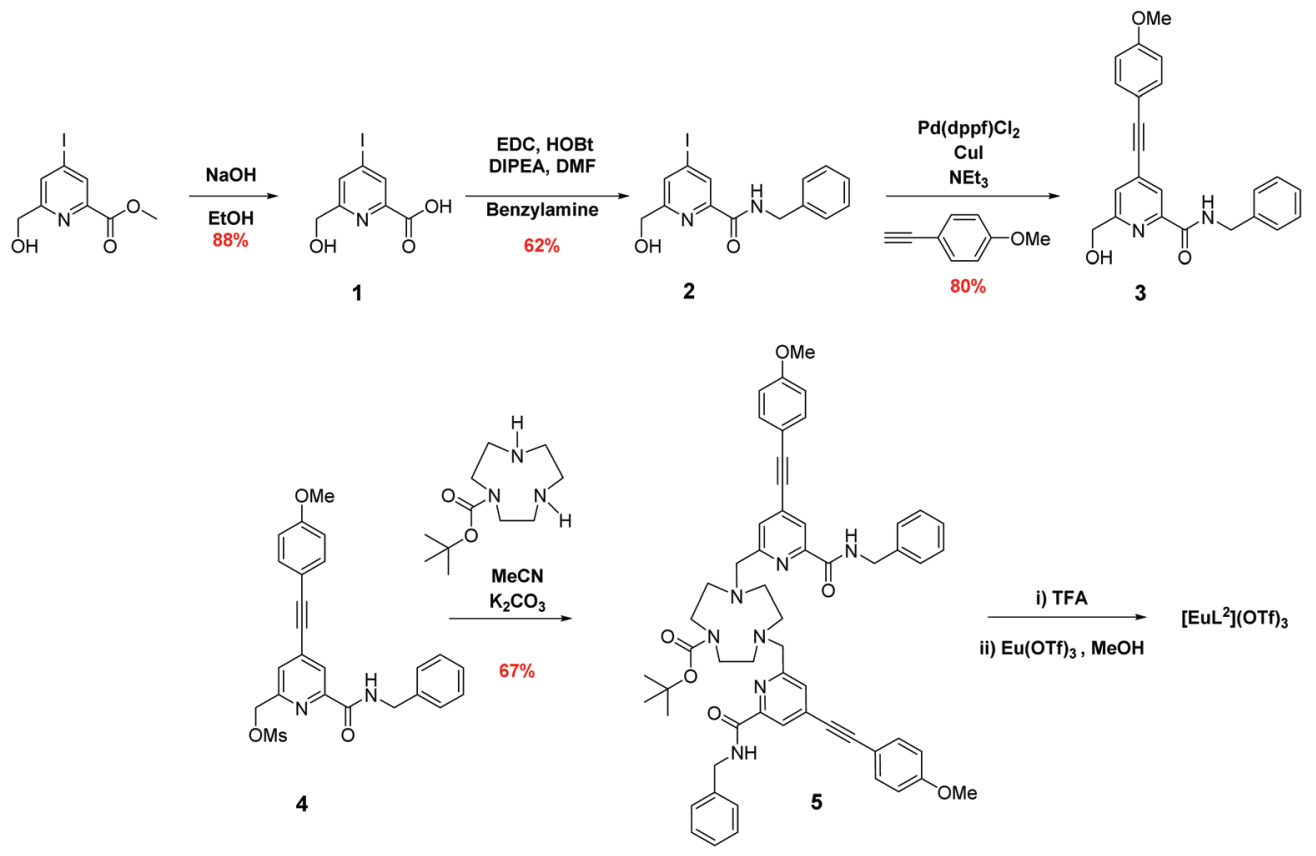

Scheme 1 Synthesis of $L^{2}$ and its Eu(III) complex.
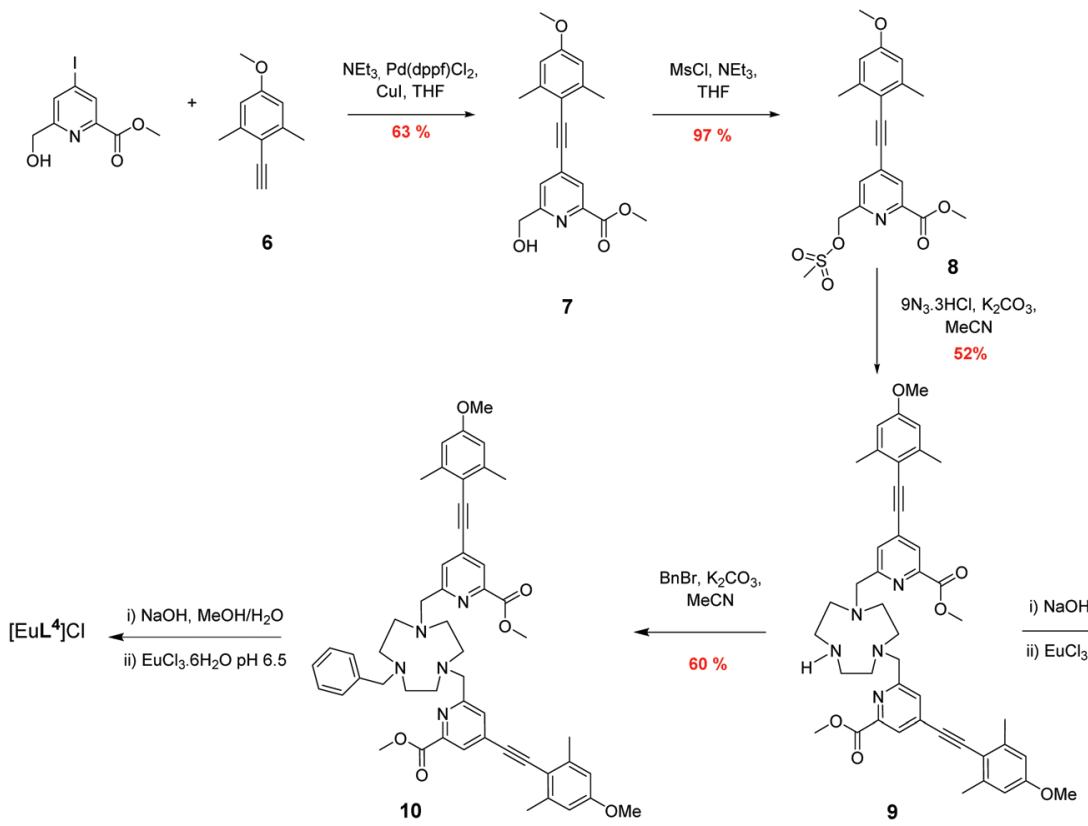

Scheme 2 Synthesis of ligands $\mathrm{L}^{3}$ and $\mathrm{L}^{4}$ and their Eu(III) complexes.

of mono-BOC-9- $\mathrm{N}_{3}$ with two equivalents of the mesylate, 4, gave the carbamate 5, from which the Eu(III) complex was prepared following TFA de-protection and reaction with europium triflate in methanol. A similar sequence was used to prepare the carboxylate ligands $\mathrm{L}^{3}$ and $\mathrm{L}^{4}$ (Scheme 2), ${ }^{23}$ except that dialkylation of the parent tri-amine was used, in order to obviate exposure of the electron-rich alkyne to strongly acidic conditions, as it is rather sensitive to acid-catalysed alkyne hydration.

Photophysical data, summarising the behaviour of the four Eu(III) complexes in methanol (Table 1), highlights the differences between the complexes. The high absorbance of each 
Table 1 Photophysical properties of the Eu(III) complexes of $\mathrm{L}^{1-4}$ $(295 \mathrm{~K}, \mathrm{MeOH}$; selected emission decay rate constant data are given in water) $)^{a, b}$

\begin{tabular}{lllll}
\hline & {$\left[\mathrm{Eu} \cdot \mathbf{L}^{1}\right]^{+}$} & {$\left[\mathrm{Eu} \cdot \mathbf{L}^{2}\right]^{3+}$} & {$\left[\mathrm{Eu} \cdot \mathbf{L}^{3}\right]^{+}$} & {$\left[\mathrm{Eu} \cdot \mathbf{L}^{\mathbf{4}}\right]^{+}$} \\
\hline$\lambda / \mathrm{nm}$ & 332 & 348 & 352 & 348 \\
$\varepsilon / \mathrm{mM}^{-1} \mathrm{~cm}^{-1}$ & 38.6 & 40.0 & 35.0 & 36.0 \\
$\Phi$ & 0.19 & 0.02 & 0.20 & 0.18 \\
$k / \mathrm{ms}^{-1}$ & 2.94 & 2.17 & 2.56 & 1.20 \\
$k \mathrm{H}_{2} \mathrm{O} / \mathrm{ms}^{-1}$ & 2.97 & 3.85 & 3.70 & 2.00 \\
$k \mathrm{D}_{2} \mathrm{O} / \mathrm{ms}^{-1}$ & 2.04 & 2.33 & 2.63 & 1.89 \\
$q$ & 0.8 & 1.3 & 1.0 & 0
\end{tabular}

${ }^{a}$ Data for $\left[\mathrm{Eu} \cdot \mathbf{L}^{\mathbf{1}}\right]^{+}$is taken from ref. 28 ; errors on $k$ values are $\pm 10 \%$ and $\pm 20 \%$ on quantum yield values; ${ }^{b} q$ values in water were determined as defined in ref. 32, using the equation $q=1.2\left\{\left(k\left(\mathrm{H}_{2} \mathrm{O}\right)-\right.\right.$ $\left.k\left(\mathrm{D}_{2} \mathrm{O}\right)-0.26-0.075 n\right\}$ where $n$ is the number of $\mathrm{NH}$ oscillators for secondary amide groups coordinated to Eu via the amide carbonyl.

complex in the range 332 to $352 \mathrm{~nm}$ arises from the strong ICT band. $^{23,28}$ The amide complex, $\left[\mathrm{Eu} \cdot \mathbf{L}^{2}\right]^{3+}$, possesses a modest overall emission quantum yield (2\%-presumably due to less favourable intramolecular energy transfer) whereas the other complexes have quantum yields in the range 18 to $20 \%$. These are high values, especially for systems with both a coordinated secondary amine group and a bound water molecule. The presence of a coordinated amine $\mathrm{NH}$ oscillator has been shown to be particularly effective at quenching the Eu(III) excited state, via efficient vibrational coupling. ${ }^{32,33}$ Such excited-state quenching explains the faster emission decay rate compared to the $N$-benzyl complex, $\left[\mathrm{Eu} \cdot \mathbf{L}^{4}\right]^{+}$, where the observed rate of emission is nearly twice as slow in methanol. Measurements of the rate constants defining the decay rate of $\mathrm{Eu}(\mathrm{III})$ emission in water and $\mathrm{D}_{2} \mathrm{O}$ allowed solvation states to be estimated. Such data shows that the complexes of $\mathrm{L}^{1-3}$ are octadentate, with one bound water molecule. The $N$-benzyl complex, $\left[\mathrm{Eu} \cdot \mathbf{L}^{4}\right]^{+}$, does not possess a bound water molecule, presumably because of the increased steric demand imposed by the additional benzylic substituent. It represents an unusual example of a seven-coordinate Eu(III) complex in aqueous solution, although the emission quantum yield is less than $\left[\mathrm{Eu} \cdot \mathbf{L}^{3}\right]^{+}$, perhaps due to a less efficient energy transfer step.

\section{Binding affinity with added chiral anions}

Incremental addition of aqueous solutions containing a given chiral anion, to each Eu complex in turn, was monitored by emission spectroscopy, examining changes in the relative intensity and form of the $\mathrm{Eu}(\mathrm{III})$ emission spectrum (Fig. 1). The relative intensity of the $\Delta J=2$ and $\Delta J=1$ emission bands was plotted as a function of anion concentration and the variation was fitted to a $1: 1$ binding model by non-linear leastsquares fitting, to give an estimate of the association constant. Direct observation of the $1: 1$ adduct was obtained by electrospray mass spectrometry (ESI), for examples with added lactate, mandelate and $\alpha$-hydroxycyclohexylacetate. The limited water solubility of the Eu complexes of the mono-cationic complexes meant that these systems were examined in 50\% aqueous methanol. Overall, the observed emission intensity increased as anion was added; changes in spectral form were most significant with $\left[\mathrm{Eu} \cdot \mathbf{L}^{\mathbf{1}}\right]^{+},{ }^{28}$ and were least marked with the complexes of $\mathrm{L}^{2-4}$. The overall changes in emission spectral form were the same for enantiopure and racemic samples of the added chiral anion (ESI, Fig. S2b $\dagger$ ).

Binding constants (Table 2) were largest for the anions with the bulkier substituents (cyclohexyl $>\mathrm{Ph}>\mathrm{Me}$ ) that are intuitively more hydrophobic, consistent with a major role for anion desolvation in the overall free energy change. Thus, binding constants with cyclohexylhydroxyacetate were the highest in every case. Comparing the behaviour of $\left[\mathrm{Eu} \cdot \mathbf{L}^{3}\right]^{+}$and its $N$-benzyl analogue, $\left[\mathrm{Eu} \cdot \mathbf{L}^{4}\right]^{+}$, affinity constants were smaller for the latter, $q=0$ complex. The favourable free energy term associated with displacement of the weakly Eu-coordinated water and its return to bulk (where it enjoys full hydrogen bonding to other water molecules) presumably accounts for this difference in behaviour. In the lactate series, strongest binding occurred to the most positively charged complex, $\left[\mathrm{Eu} \cdot \mathbf{L}^{2}\right]^{3+}$; the phosphinate complex, $\left[\mathrm{Eu} \cdot \mathbf{L}^{\mathbf{1}}\right]^{+}$bound anions most weakly, notably compared to the carboxylate, $\left[\mathrm{Eu} \cdot \mathbf{L}^{3}\right]^{+}$.

These stability data are based on total emission changes for all stereoisomeric anion adducts, irrespective of their configuration or constitution. By examining the change in $g_{\mathrm{em}}$ with added anion concentration, information is gained on the stability of the major chiral species, i.e. the $\Delta$ over the $\Lambda$ isomeric species. Such a comparison was undertaken for $\left[\mathrm{Eu} \cdot \mathbf{L}^{3}\right]^{+}$

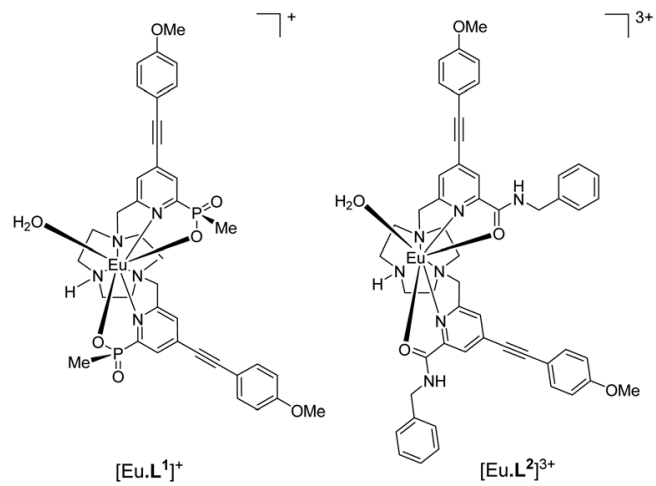

$\left[\text { Eu.L }{ }^{1}\right]^{+}$

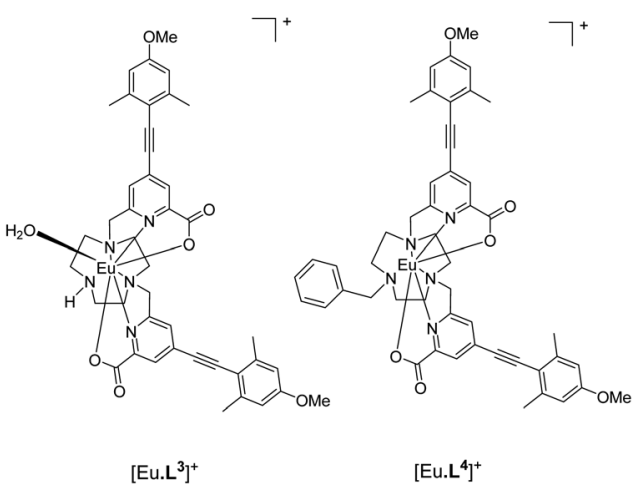

This journal is @ The Royal Society of Chemistry 2015 

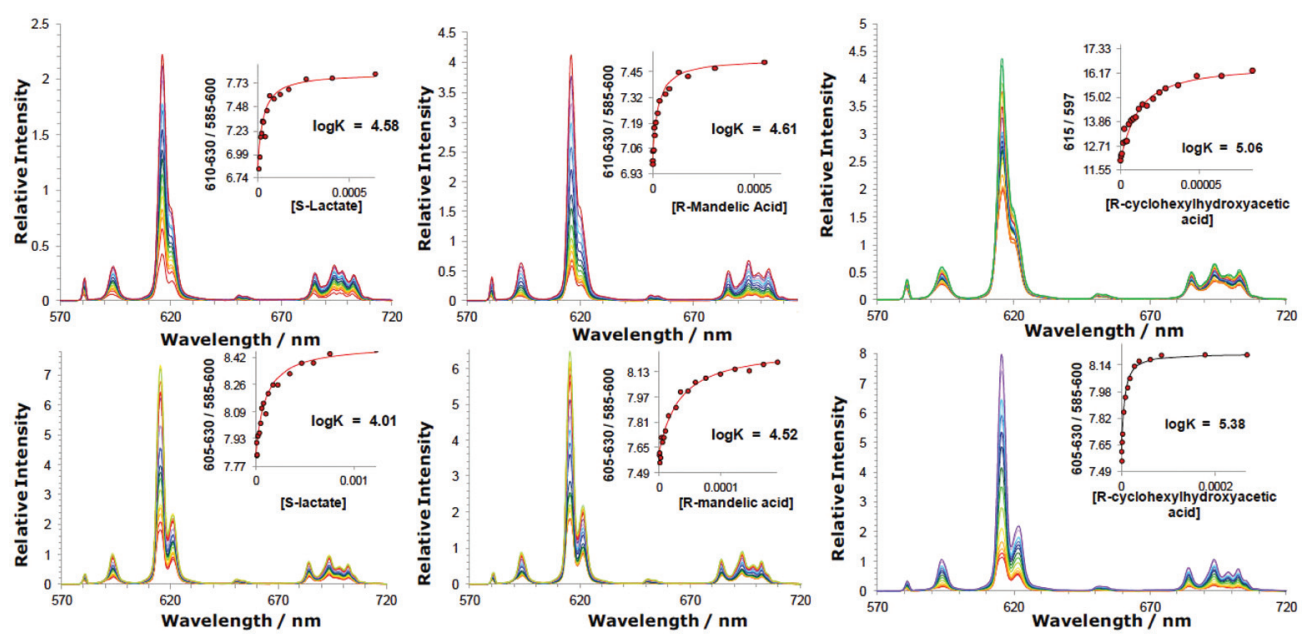

Fig. 1 Variation of the europium(III) emission profile as a function of added anion; (upper): [Eu. $\left.L^{2}\right]^{3+}\left(5 \mu \mathrm{M} ; \lambda_{\text {exc }} 348 \mathrm{~nm}, \mathrm{H}_{2} \mathrm{O}, \mathrm{pH} 5.5\right)$, (left to right) lactate, mandelate and cyclohexylhydroxyacetate; (lower): [Eu. $\left.\mathrm{L}^{3}\right]^{+}(5 \mu \mathrm{M})\left(\lambda_{\text {exc }}=352 \mathrm{~nm}, 50 \% \mathrm{MeOH}\right.$ in $\mathrm{H}_{2} \mathrm{O}$, pH 5.5) plus added anions. Insets show fits to experimental data, following iterative non-linear least-squares fitting to a $1: 1$ binding model (details in the ESI $\dagger$ ). No significant differences in measured binding constants were found with enantiomeric carboxylates.

Table 2 Binding constants, log $K$, for chiral anion complexation $(295 \mathrm{~K}$, $50 \%$ aq. $\mathrm{MeOH})^{a, b, c, d}$

\begin{tabular}{llll}
\hline & $R$-lactate & $R$-mandelate & $\begin{array}{l}R \text {-cyclohexyl- } \\
\text { hydroxyacetate }\end{array}$ \\
\hline$\left[\mathrm{Eu} \cdot \mathbf{L}^{1}\right]^{+}$ & $2.76(04)[2.41]^{a}$ & - & - \\
{$\left[\mathrm{Eu} \cdot \mathbf{L}^{2}\right]^{3+}$} & $4.57(05)[4.58]^{a}$ & $4.61(06)^{a}$ & $5.06(05)^{a}$ \\
{$\left[\mathrm{Eu} \cdot \mathbf{L}^{3}\right]^{+}$} & $4.01(04)$ & $4.52(06)$ & $5.38(04)$ \\
{$\left[\mathrm{Eu} \cdot \mathbf{L}^{4}\right]^{+}$} & $3.15(04)$ & $3.85(04)$ & $4.41(05)$
\end{tabular}

${ }^{a}$ Measurement in water only at $\mathrm{pH} 5.5$ to eliminate the possibility of interference from bicarbonate. ${ }^{b}$ Binding of $R$-phenylpropionic acid was weak with $\log K$ estimated to be less than 1.5 for the complexes of $\mathrm{L}^{2-4} \cdot{ }^{c}$ Errors associated with the fitting analysis of a given data set are given in parentheses; experimental errors were estimated to be \pm 0.1 $\log$ unit. ${ }^{d}$ Bicarbonate forms an adduct with each of these complexes, ${ }^{28}$ and the relative affinity (and sensitivity) fell in the order: $\left[\mathrm{Eu} \cdot \mathrm{L}^{2}\right]^{3+}>\left[\mathrm{Eu} \cdot \mathrm{L}^{3}\right]^{+} \gg\left[\mathrm{Eu} \cdot \mathrm{L}^{1}\right]^{+}>\left[\mathrm{Eu} \cdot \mathrm{L}^{4}\right]^{+}$. with $R$-mandelate, by measuring the variation in $g$ with added anion compared to the total emission change. The experiment was carried out in methanol solution to optimise the CPL signal intensity (Fig. 2). In pure methanol solution, binding affinities are higher due to the smaller free energies of anion solvation. A slightly higher stability constant was found $(\log K$ $=5.79$ vs. 5.44) in this case, consistent with a slightly higher binding affinity for the favoured isomer (vide infra: this has a $\Delta$ configuration for the $R$-mandelate). Similar behaviour occurred for the other systems described here.

Further information on the constitution of the anion adduct in each case can be gained by examining the emission decay rates of the anion adducts in water and $\mathrm{D}_{2} \mathrm{O}$. A coordinated $\alpha$-hydroxy-carboxylate in a 5 -ring chelate, means that there is one $\mathrm{OH}$ oscillator in the Eu coordination environment. A quenching effect that is half of that created by a coordinated water occurs, assuming that the Ln-O distances are about the same. Earlier work substantiates this view, and X-ray studies of
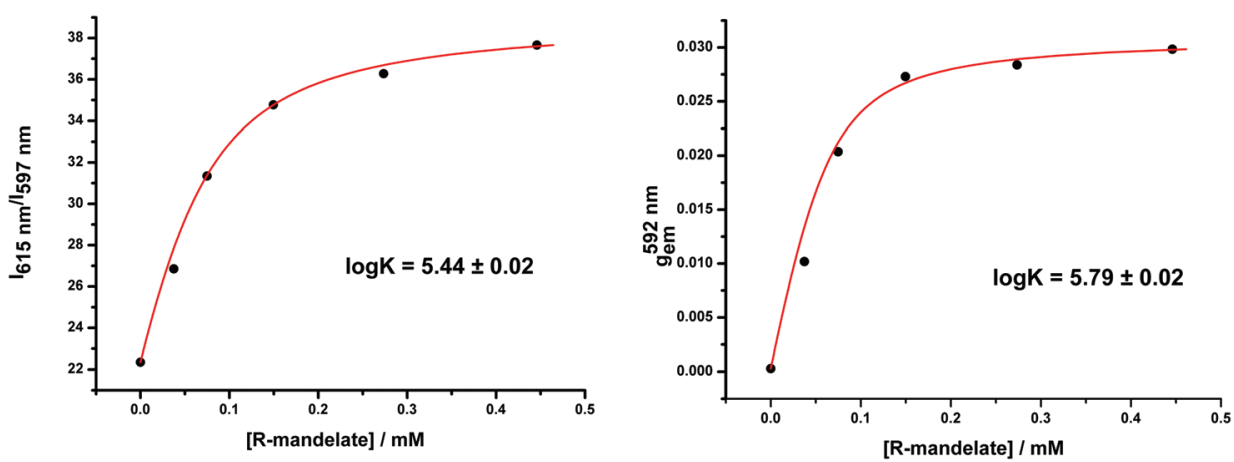

Fig. 2 Left: Variation of the ratio of two emission wavelengths vs. the concentration of mandelate; right: variation of the emission dissymmetry value $g_{\mathrm{em}}$ at $592 \mathrm{~nm}$ vs. concentration of mandelate. Experimental data fit to a 1:1 binding model following iterative least-squares fitting. $(6 \mu \mathrm{M}$ complex, $\left.\lambda_{\text {exc }}=352 \mathrm{~nm}, \mathrm{MeOH}\right)$. 
Table 3 Emission decay rate constants characterising Eu emission in the presence and absence of $R$-lactate $(295 \mathrm{~K}, 10 \mu \mathrm{M}$ complex, $50 \mu \mathrm{M}$ lactate)

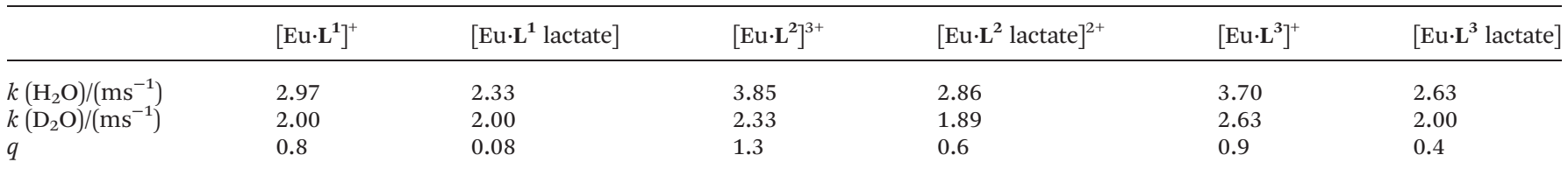
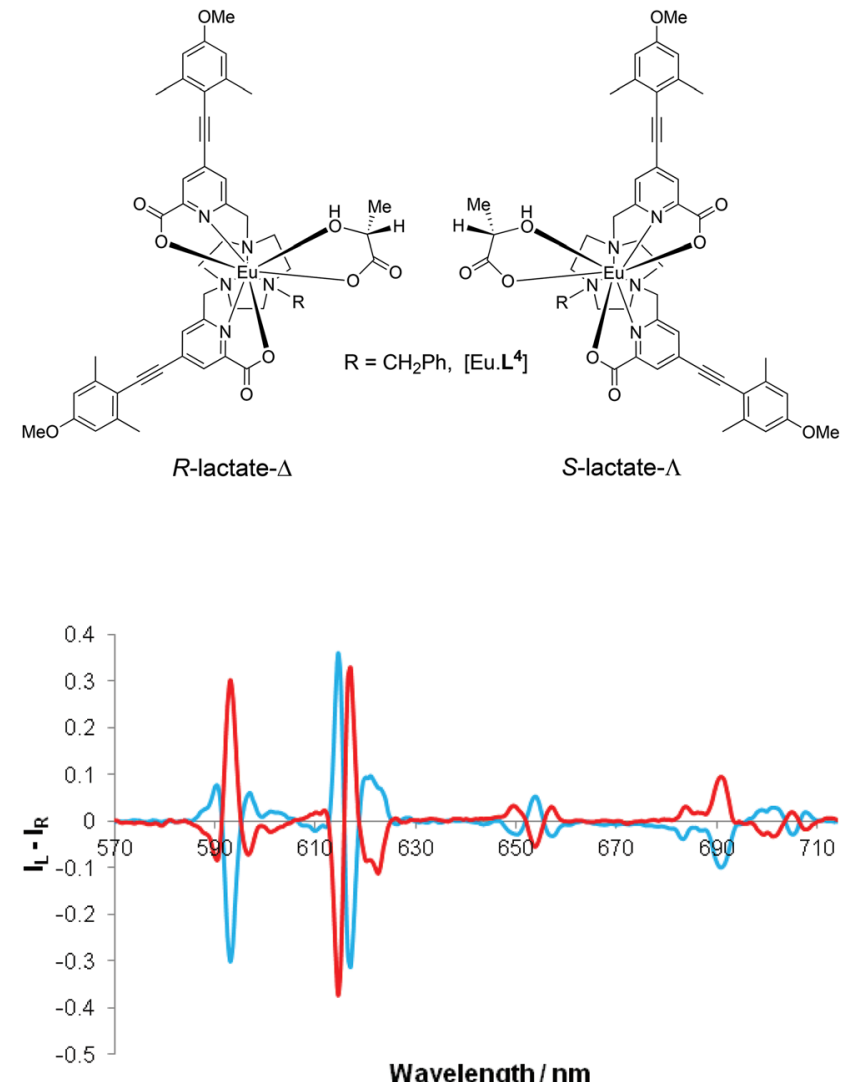

Fig. 3 Mirror image CPL spectra of $\left[\mathrm{Eu} \cdot \mathrm{L}^{4}\right]^{+}$following addition of $R$-(red) and $S$-(blue) lactate $\left(\lambda_{\text {exc }}=348 \mathrm{~nm}, 10 \mu \mathrm{M}\right.$ complex, $50 \mu \mathrm{M}$ lactate, $295 \mathrm{~K}, \mathrm{MeOH}$ ); (upper) showing the putative major isomers that gives rise to the observed CPL.

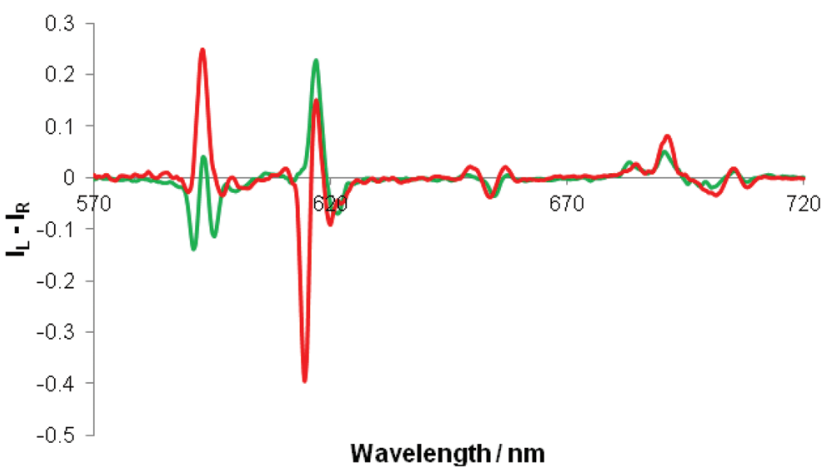

Fig. $4 \mathrm{CPL}$ spectra of $\left[\mathrm{Eu} \cdot \mathrm{L}^{4}\right]^{+}$following addition of $R$-phenylpropionic acid (green) and $R$-cyclohexylhydroxyacetic acid (red). $\left(\lambda_{\text {exc }} 348 \mathrm{~nm}\right.$, $2 \mathrm{mM}$ anion, $5 \mu \mathrm{M}$ complex, MeOH, pH 5.5, $295 \mathrm{~K})$. chelated lactate and citrate adducts show a Ln-O bond distance that is within $0.05 \AA$ of the corresponding hydrated complexes. ${ }^{29,32}$ The rate data obtained (Table 3), shows that the lactate adduct for $\left[\mathrm{Eu} \cdot \mathbf{L}^{1}\right]^{+}$has no coordinated $\mathrm{OH}$ group, implying carboxylate binding only, whereas there is a bound hydroxyl group for complexes of $\mathbf{L}^{2}$ and $\mathbf{L}^{3}$.

\section{Induced CPL following binding of enantiopure acids}

Separate addition of $R$ and $S$ enantiomers of a given chiral acid gave rise to mirror image induced circularly polarised luminescence (Fig. 3). The CPL spectra were very weak following addition of chiral acids lacking a coordinating $\alpha$-substituent (e.g. $S$-ibuprofen, $R$-camphanic acid, $R$-phenylsuccinic acid), but were much stronger generally with $\alpha$-hydroxy acids (e.g. lactic, mandelic, malic, cyclohexylhydroxyacetic). Furthermore, their circularly polarised luminescence spectrum were better resolved than the total emission spectrum in each case, notably in the $\Delta J=1$ and $\Delta J=4$ manifolds around 590 and $700 \mathrm{~nm}$. The $N$-benzyl complex, $\left[\mathrm{Eu} \cdot \mathbf{L}^{4}\right]^{+}$, gave rise to the strongest CPL spectra, amongst the systems studied, for the simple carboxylic acids. The CPL signature for the adduct of a simple chiral acid such as $R$-phenylpropionic acid was quite different to that with an $\alpha$-hydroxy acid, e.g. for [Eu. $\left.\mathbf{L}^{4}\right]^{+}$, notably in the $\Delta J=1$ and $\Delta J$ $=2$ transitions around 590 and $620 \mathrm{~nm}$ respectively (Fig. 4).

For a given chiral acid, analysis of scalemic mixtures by CPL allowed an assessment of sample enantiomeric purity, as exemplified with mandelate using $\left[\mathrm{Eu} \cdot \mathbf{L}^{3}\right]^{+}$, (Fig. 5). It should be noted that this analytical method requires prior calibration with an enantiopure sample before it can be employed; inherently, it provides information about sample enantiomeric purity and absolute configuration.

It was found that the $R$ - $\alpha$-hydroxy acids each gave rise to a common induced CPL signature in the $\Delta J=4$ region, across the whole series of Eu complexes used in this study, (Fig. 6), allowing the absolute configuration of a given chiral acid to be distinguished readily using any of these complexes. This surprising empirical observation could not be extended to analysis of every CPL transition, although certain correlations were found (Table 4). The induced CPL spectra for these adducts were compared to those reported for the related $C_{3}$-symmetric, 9-coordinate complexes, $\left[\mathrm{Eu} \cdot \mathbf{L}^{5-7}\right]$, whose structure and absolute configuration have been established by crystallographic analyses..$^{2,28,34}$ A tentative correlation was found within a given series, allowing assignment of the $R$-acid adducts compared to the configuration of their respective parent complexes, in every case, to a $\Delta$ complex configuration, with a $\lambda \lambda \lambda$ configuration for the three EuNCCN chelates of the 9-ring. 


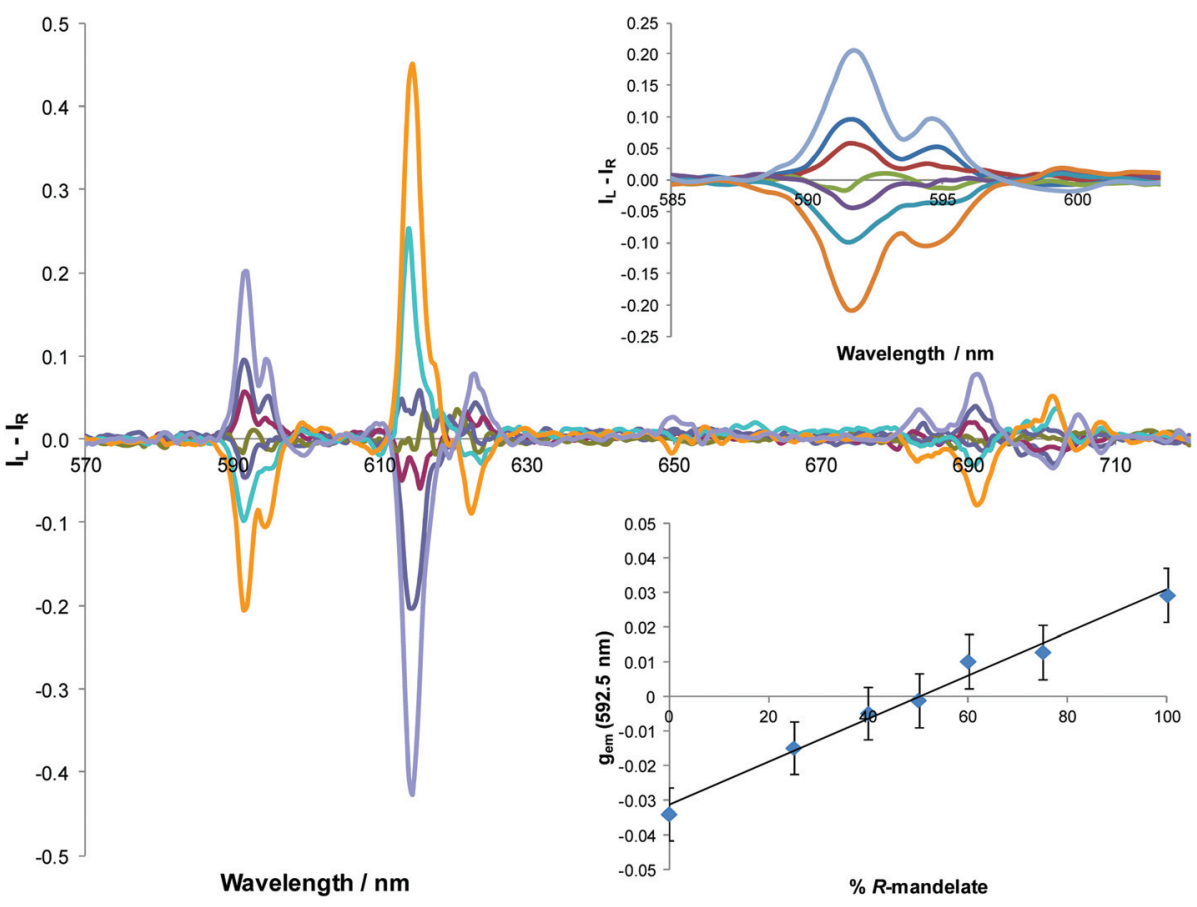

Fig. 5 Changes in the CPL spectrum of $\left[E u \cdot L^{3}\right]^{+}$following addition of mandelate of varying enantiomeric composition $\left(10 \mu \mathrm{M}, \lambda_{\text {exc }}=352 \mathrm{~nm}\right.$, $\mathrm{MeOH})$. Inset (top) shows the $\Delta J=1$ manifold; (bottom) variation of $g_{\mathrm{em}}(592.5 \mathrm{~nm})$ with $\% R$-mandelate; error bars indicate the standard deviation averaged over 5 runs $\left(R^{2} 0.98\right.$ for shown linear fit).

\section{Stereochemistry of the anion adducts: NMR and DFT studies}

In order to gain further understanding of the structures of the isomeric complexes and lactate adducts, hybrid-DFT calculations were performed. As the paramagnetic europium(III) complexes are very difficult to model computationally, optimised geometries of the analogous diamagnetic yttrium(III) complexes have been investigated. It has been shown that they serve as suitable models for the $\mathrm{Eu}$ analogues; ${ }^{23,31,35-37}$ indeed, the $\mathrm{Y}(\mathrm{III})$ ion differs from the Eu(III) ion in ionic radius by only $0.05 \AA$ A. Excellent agreement was observed comparing bond lengths for the optimised geometries of yttrium(III) complexes at B3LYP/3-21G* with the reported X-ray diffraction geometries (ESI Tables S1 and $\mathrm{S} 2 \dagger$ ). This agreement indicates that the functional/basis set of B3LYP/3-21G* gives accurate model geometries of yttrium complexes with confidence and B3LYP/ $3-21 G^{*}$ is perhaps superior to alternative reported ${ }^{23,31,35-37}$ functionals and basis sets. A Y(III) model geometry from a reported $^{34} \mathrm{X}$-ray geometry of a related europium complex optimised at B3LYP/3-21G* gave an excellent representation of the $\mathrm{Eu}(\mathrm{III}) \mathrm{X}$-ray geometry (ESI Table $\mathrm{S} 3 \dagger$ ). The $\mathrm{Y}-\mathrm{O}$ and $\mathrm{Y}-\mathrm{N}$ bond lengths are shorter by $0.05 \AA$ on average compared to the corresponding $\mathrm{Eu}-\mathrm{O}$ and $\mathrm{Eu}-\mathrm{N}$ bonds, as expected from the established ionic radii of the $\mathrm{Y}$ (III) and $\mathrm{Eu}(\mathrm{III})$ ions in coordination number 8 or 9 complexes.

Investigation of the binding of one water molecule to each of the four complexes reveals binding energies of increasing strength in the order: $\left[\mathrm{Y} \cdot \mathrm{L}^{4}\right]^{+}<\left[\mathrm{Y} \cdot \mathrm{L}^{1}\right]^{+}<\left[\mathrm{Y} \cdot \mathrm{L}^{3}\right]^{+}<\left[\mathrm{Y} \cdot \mathrm{L}^{2}\right]^{3+}$ (Fig. 7, ESI Table $\mathrm{S} 4 \dagger)$. This sequence is consistent with the trend of observed radiative rate constants of decay of $\mathrm{Eu}(\mathrm{III})$ emission (Table 1). The relative energies of free and water bound conformers of $\left[\mathrm{Y} \cdot \mathrm{L}^{4}\right]^{+}$suggested an expected value of $q=1$ rather than the observed $q=0$ value derived from the emission rate constants of decay in water and $\mathrm{D}_{2} \mathrm{O}$ for $\left[\mathrm{Eu} \cdot \mathrm{L}^{4}\right]$. The steric demand imposed by the benzyl group does not appear to prevent water binding, on the basis of the calculated geometry using Y instead of Eu (Fig. 6). The discrepancy in the $q$ values may be accounted for by a different argument. The metalbound water complex may be of higher energy when the rotation of the benzyl group hinders formation of a stabilising hydrogen bond network between the coordinated water and its hydrogen-bonded (i.e. second-sphere) waters.

The binding energies of the anions $R$-lactate, $R$-mandelate and $R$-cyclohexyl- $\alpha$-hydroxyacetate with a water molecule were calculated in order to assess the relative hydrophobicity of these anions. The order of increased binding energies (ESI, Table S6 $\dagger$ ) is cyclohexyl- $\alpha$-hydroxyacetate $<$ mandelate $<$ lactate, corresponding to the sequence of binding affinities to the europium complexes that was observed experimentally (Table 2).

The binding energies of $R$-lactate with $\left[\mathrm{Y} \cdot \mathrm{L}^{1-4}\right]$ also reveal a trend that is consistent with the association constants calculated by emission spectroscopy (Table 2), where $R$-lactate binds with increasing strength in the order: $\left[\mathrm{Y} \cdot \mathrm{L}^{1}\right]^{+}<\left[\mathrm{Y} \cdot \mathrm{L}^{4}\right]^{+} \sim\left[\mathrm{Y} \cdot \mathrm{L}^{3}\right]^{+}$ $<\left[\mathrm{Y} \cdot \mathrm{L}^{2}\right]^{3+}$ (ESI Table S5 ${ }^{\dagger}$ ). Investigation of the geometries of $R$-lactate bound to $\left[\mathrm{Y} \cdot \mathrm{L}^{1}\right]^{+}$shows that the hydroxyl group of the coordinated lactate does not bind as strongly as in $\left[\mathrm{Y} \cdot \mathrm{L}^{2-4}\right]$, with a longer $\mathrm{Y}-\mathrm{O}$ distance of $2.7 \AA$ compared to corresponding distances of 2.4-2.5 $\AA$ for complexes $\left[\mathrm{Y} \cdot \mathrm{L}^{2-4}\right]$. Close 

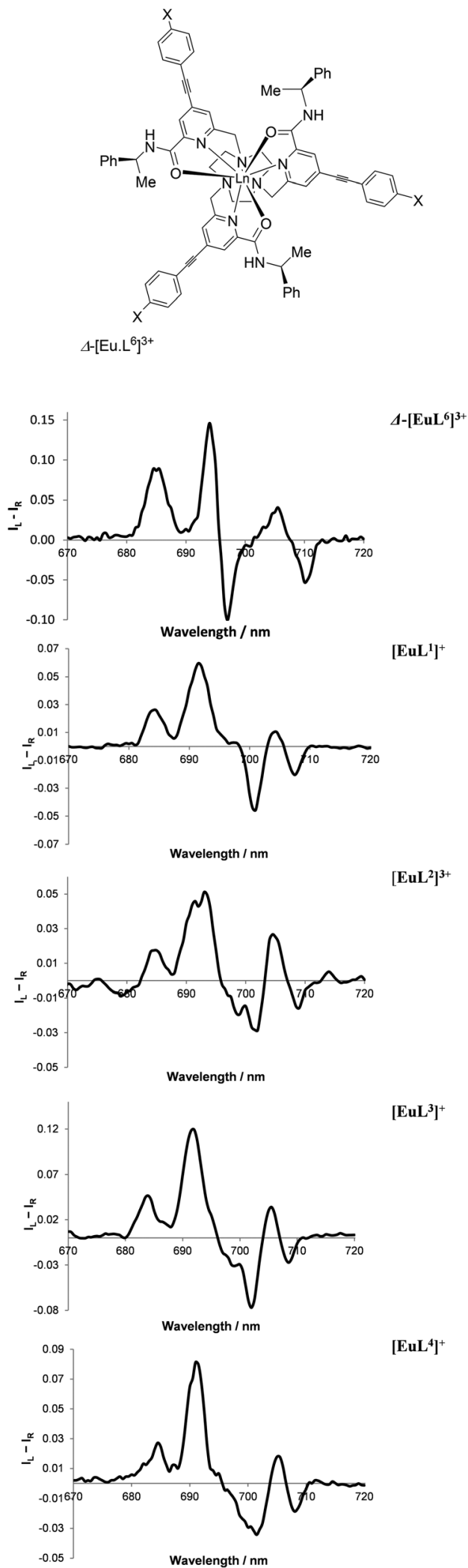

$\left[\mathrm{EuL}^{4}\right]^{+}$

Fig. 6 Partial $\mathrm{CPL}$ spectra for Eu(III) complexes of $\mathrm{L}^{1-4}$, compared to $\Delta-\left[E u \cdot L^{6}\right]^{3+}$ (top), showing the similar $\Delta J=4$ manifold in the presence of excess $R$-cyclohexylhydroxyacetic acid $\left(295 \mathrm{~K}, \mathrm{H}_{2} \mathrm{O}, 10 \mu \mathrm{M}\right.$ complex, $50 \mu \mathrm{M}$ acid), correlating with selective formation of a $\Delta$-complex in each case. Mirror image profiles were obtained adding $S$-acid (see ESI $\dagger$ for total emission and full CPL spectra of each system).
Table 4 Emission dissymmetry values, $g_{\mathrm{em}}$, for Eu(III) complexes in the presence of excess $R$-lactate, mandelate or cyclohexylhydroxyacetate

\begin{tabular}{|c|c|c|c|c|c|}
\hline & $g_{\mathrm{em}}$ & {$\left[\mathrm{Eu} \cdot \mathbf{L}^{\mathbf{1}}\right]^{+}$} & {$\left[\mathrm{Eu} \cdot \mathbf{L}^{2}\right]^{3+}$} & {$\left[\mathrm{Eu} \cdot \mathbf{L}^{3}\right]^{+}$} & {$\left[\mathrm{Eu} \cdot \mathbf{L}^{\mathbf{4}}\right]$} \\
\hline \multicolumn{6}{|c|}{$R$-Lactate } \\
\hline$\Delta J=1$ & $(592 \mathrm{~nm})$ & +0.01 & -0.03 & +0.02 & +0.05 \\
\hline \multirow[t]{4}{*}{$\Delta J=4$} & $(683 \mathrm{~nm})$ & +0.005 & +0.01 & +0.01 & +0.01 \\
\hline & $(692 \mathrm{~nm})$ & +0.02 & +0.02 & +0.01 & +0.02 \\
\hline & $(702 \mathrm{~nm})$ & -0.02 & -0.01 & -0.01 & -0.02 \\
\hline & $(708 \mathrm{~nm})$ & -0.04 & -0.04 & -0.03 & -0.06 \\
\hline \multicolumn{6}{|c|}{$R$-Mandelate } \\
\hline$\Delta J=1$ & (592 nm) & +0.01 & -0.05 & +0.04 & +0.05 \\
\hline \multirow[t]{4}{*}{$\Delta J=4$} & $(683 \mathrm{~nm})$ & +0.01 & +0.01 & +0.01 & +0.01 \\
\hline & $(692 \mathrm{~nm})$ & +0.02 & +0.02 & +0.03 & +0.03 \\
\hline & $(702 \mathrm{~nm})$ & -0.03 & -0.01 & -0.03 & -0.02 \\
\hline & $(708 \mathrm{~nm})$ & -0.09 & -0.05 & -0.06 & -0.09 \\
\hline \multicolumn{6}{|c|}{$R$-Cyclohexylhydroxyacetate } \\
\hline$\Delta J=1$ & $(592 \mathrm{~nm})$ & +0.02 & -0.05 & +0.07 & +0.06 \\
\hline \multirow[t]{4}{*}{$\Delta J=4$} & $(683 \mathrm{~nm})$ & +0.01 & +0.01 & +0.02 & +0.02 \\
\hline & $(692 \mathrm{~nm})$ & +0.02 & +0.03 & +0.04 & +0.04 \\
\hline & (702 nm) & -0.02 & -0.01 & -0.07 & -0.03 \\
\hline & $(708 \mathrm{~nm})$ & -0.09 & -0.08 & -0.09 & -0.11 \\
\hline
\end{tabular}

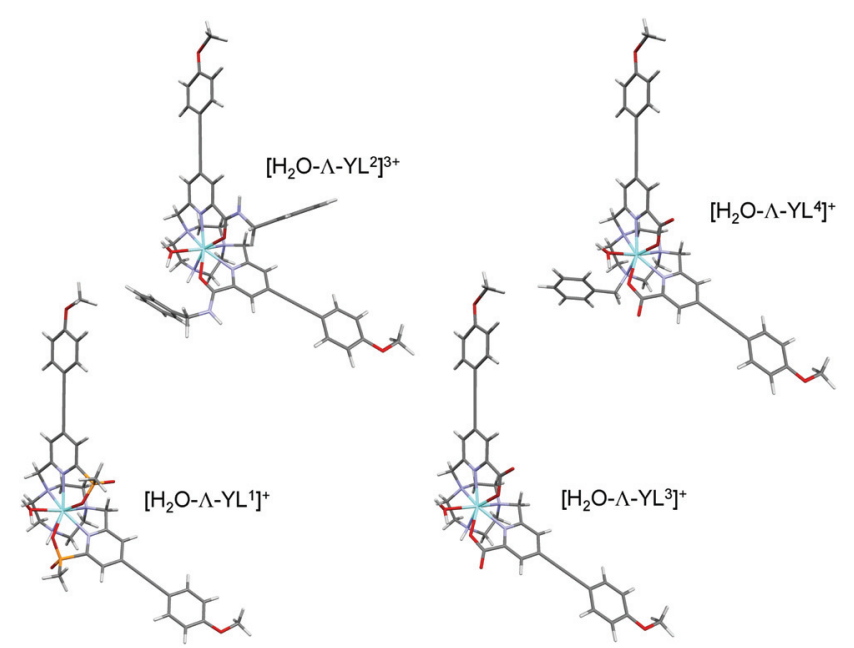

Fig. 7 Optimised geometries of $\Lambda-\left[Y \cdot L^{1-4}\right]$ as their mono-aqua complexes.

inspection of the optimised geometries of the $R$-lactate $\left[\mathrm{Y} \cdot \mathrm{L}^{1-4}\right]$ adducts, reveals that the phosphinate groups in $\left[\mathrm{Y} \cdot \mathrm{L}^{1}\right]^{+}$are more sterically bulky than the corresponding amide or carboxylate donors in $\left[\mathrm{Y} \cdot \mathrm{L}^{2-4}\right]$. The increased steric demand results in less space being available for lactate binding via chelation (Fig. S7 $\dagger$ ). This interpretation lends support to the hypothesis that lactate coordinates to $\left[\mathrm{Y} \cdot \mathrm{L}^{1}\right]^{+}$via the carboxylate group, either in a monodentate manner or via a 4-membered chelate. Such a hypothesis is corroborated by the differences in the observed radiative decay rate constants (Table 3).

The constitution and relative stereochemistry of the isomeric adducts with a given Eu complex are difficult to determine in solution, without a crystallographic analysis. In principle, chelation of an $\alpha$-hydroxy-acid for example, may give rise to four isomeric species: according to the orientation of 


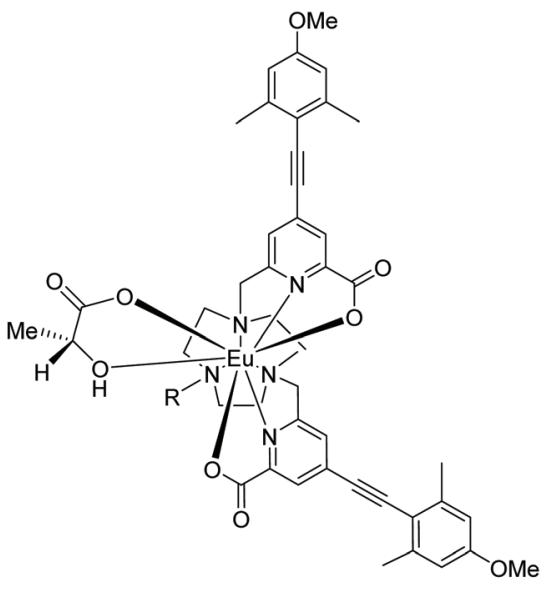

$R$-lactate- $\Lambda$

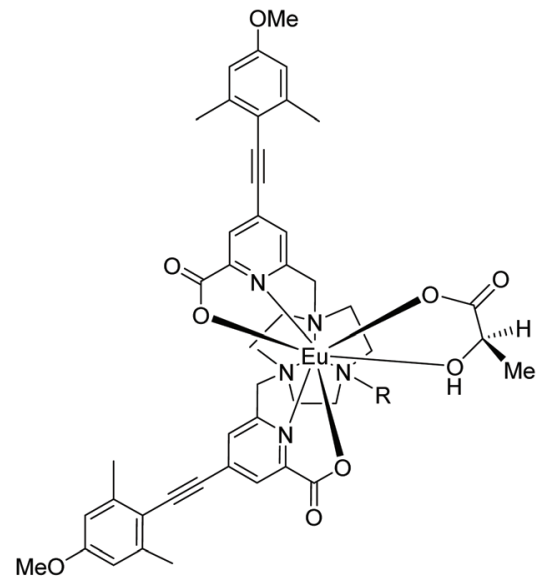

$R$-lactate- $\Delta$

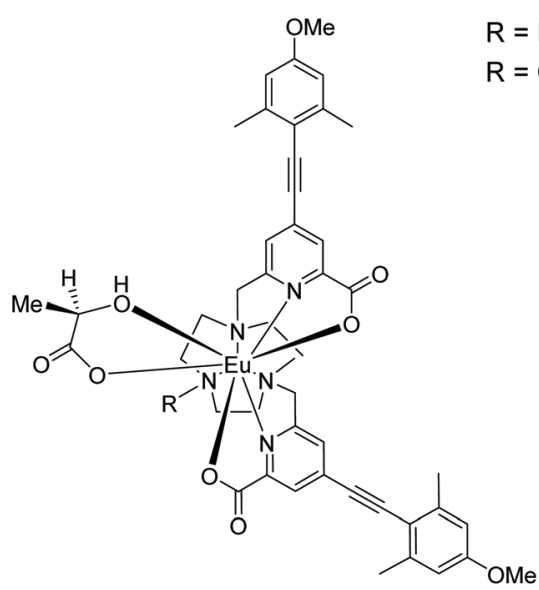

$R$-lactate- $\Lambda$

$$
\begin{aligned}
& \mathrm{R}=\mathrm{H}:\left[\mathrm{Eu} \cdot \mathrm{L}^{3}\right] \\
& \mathrm{R}=\mathrm{CH}_{2} \mathrm{Ph}:\left[\mathrm{Eu} \cdot \mathrm{L}^{4}\right]
\end{aligned}
$$
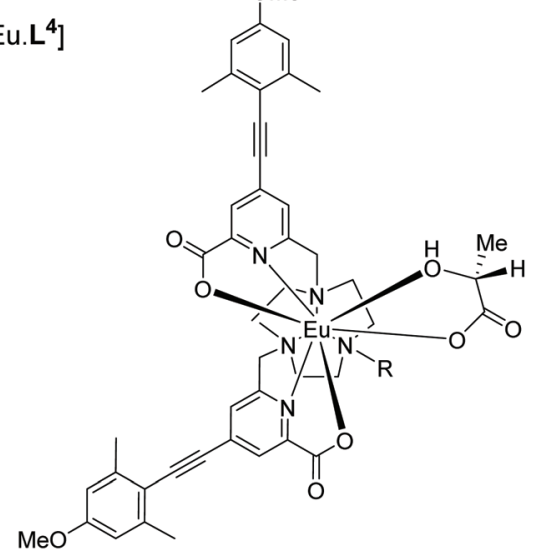

$R$-lactate- $\Delta$

Scheme 3 Structures of the four isomeric adducts theoretically arising from chelation of $R$-lactate in either sense to $\left[\text { Eu. } L^{3}\right]^{+}$and $\left[E u \cdot L^{4}\right]^{+} ;$the lower $\Delta$-isomer is hypothesised to predominate in solution.

the $\alpha$-hydroxy chelate and the $\Delta / \Lambda$ complex configuration (Scheme 3). ${ }^{1} \mathrm{H}$ NMR analysis $\left(\mathrm{CD}_{3} \mathrm{OD}\right)$ of the solvent and complex adducts were compromised by considerable linebroadening and the relatively small dipolar shifts that characterise these types of complex, associated with their relatively small ligand field splitting. ${ }^{12}$ Nevertheless, addition of $R$-lactate to $\left[\mathrm{Eu} \cdot \mathbf{L}^{3}\right]^{+}$led to a general sharpening of the observed resonances and the most shifted axial ring proton resonance (by analogy with the analysis of $\left[\mathrm{Eu} \cdot \mathbf{L}^{7}\right]$ ), was observed to shift to lower frequency $\left(\Delta \delta_{\mathrm{H}}=-1.5 \mathrm{ppm}\right)$ compared to the solvate species; four species were observed in relative ratio $3: 1: 0.8: 0.7(295 \mathrm{~K}, 11.7 \mathrm{~T})$.

Calculations were performed to assess the relative energies of the four isomeric adducts depicted as Y(III) complexes, in an attempt to reveal whether the presence of non-bonding steric interactions could rationalise the preferred formation of a particular isomer. For each yttrium complex, the preferred constitution of the lactate chelate placed the 2-pyridyl nitrogen atoms in the same plane as the lactate carboxylate oxygen (ESI Table S7 $\dagger$ ). Thus, the lowest energy isomer (Scheme 3, bottom right) possesses a $\Delta$ configuration for the $R$-lactate adduct, consistent with the assignment of configuration using the CPL data. The energy difference between the two low energy isomers increases in the order $\left[\mathrm{Y} \cdot \mathrm{L}^{2}\right]^{3+}<\left[\mathrm{Y} \cdot \mathrm{L}^{3}\right]^{+}<\left[\mathrm{Y} \cdot \mathrm{L}^{1}\right]^{+}<$ $\left[\mathrm{Y} \cdot \mathrm{L}^{4}\right]^{+}$. Such a sequence accords with the observation that the $N$-benzyl complex $\left[\mathrm{Eu} \cdot \mathrm{L}^{4}\right]^{+}$has the highest $g_{\text {em }}$ values for $70 \%$ of the induced CPL transitions in the complexes studied here. Inspection of the calculated geometries shows that in the $R$-lactate adduct, the Me group points away from a coordinated carboxylate oxygen lone pair (Fig. 8); i.e. such an interaction destabilises the $S$-lactate- $\Delta$ adduct formation.

\section{Summary and conclusions}

The helicity of this class of complexes based on the 9- $\mathrm{N}_{3}$ ring can be controlled by introduction of a stereogenic centre into the ligand structure. Thus, C-substitution into the 2 position of the macrocyclic 9-membered ring with an $R$ configuration leads to formation of $>98 \%$ of the $\Delta$ complex for the phos- 


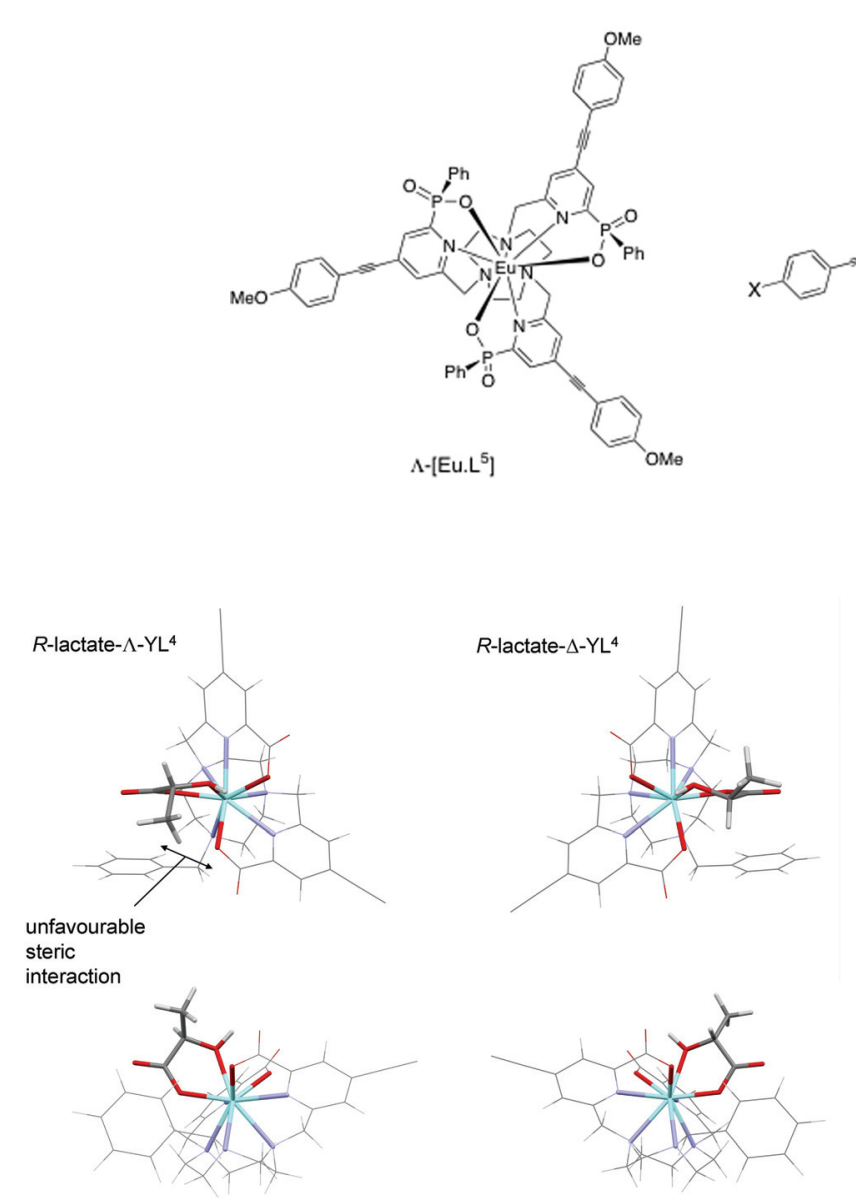

Fig. 8 Optimised geometries of $R$-lactate- $\Lambda$ - $\left[Y \cdot L^{4}\right]^{+}$and $R$-lactate- $\Delta$ $\left[Y \cdot L^{4}\right]^{+}$with two views of each complex; the anisyl groups are omitted for clarity. Both geometries show the Me group pointing away from a coordinated carboxylate oxygen lone pair, with the $\Delta$ configuration favoured owing to a less unfavourable steric interaction.

phinate and carboxylate series. ${ }^{3,26}$ The presence of an $R$ stereocentre in the amide moiety (as in $R-\left[\mathrm{Eu} \cdot \mathbf{L}^{6}\right]^{3+}$ ), above, gives rise to selective formation of the $\Lambda$ complex (a $15: 1$ ratio in this case). ${ }^{34}$ These two recent examples, describing covalent modification of the ligand structure suggest a degree of cooperativity or chiral amplification in formation of the preferred complex helicity, as defined by the sign of the three $\mathrm{NCCN}_{\mathrm{py}}$ torsion angles.

In the new work discussed here, there are only two such $\mathrm{NCCN}_{\mathrm{py}}$ torsion angles; non-covalent formation of a ternary complex with enantiopure anions has been examined. A common pattern emerged: an $R$ acid configuration favours formation of a $\Delta$ complex and leads to a strong induced CPL signal. The NMR and DFT studies provide some supporting evidence for this analysis: a preferred major isomer was observed in which the anion carboxylate lies in the same plane as the pyridyl nitrogens. The induced CPL $g_{\text {em }}$ values are significant albeit lacking the very high stereoselectivity and larger $g_{\mathrm{em}}$ values that characterise the behaviour of the more conformationally rigid, trisubstituted 9-coordinate systems.
The substitution of the third $\mathrm{N}$ position plays a key role. The $N$-benzyl complex gave the highest $g_{\text {em }}$ values for $70 \%$ of the induced CPL transitions, consistent with the tentative hypothesis that the $N$-benzyl may align helically in the same sense as the two coordinated pyridylmethyl groups to create a slightly more rigidified local chiral structure.

Finally, this work provides a starting point for developing enhanced selectivity in the association of the chiral analyte. For example, based on the $N$-benzyl system, introduction of charged groups or directed hydrogen bonding or chelating moieties, e.g. $\mathrm{NH}_{2} \mathrm{Me}^{+}$or a boronic acid group, into the benzyl ring may allow additional stabilising interactions to occur that will enhance affinity and stereoselectivity. The outcome of such work will be reported subsequently.

\section{Experimental}

Details of the synthesis of the stated precursors, general experimental aspects and spectroscopic, analytical and computational methods are given in the ESI. $\uparrow$

\section{$N$-Benzyl-6-(hydroxymethyl)-4-iodopicolinamide, 2}<smiles>O=C(NCc1ccccc1)c1cc(I)cc(CO)n1</smiles>

HOBt $\cdot \mathrm{H}_{2} \mathrm{O}(254 \mathrm{mg}, 1.88 \mathrm{mmol})$, EDC (292 mg, $\left.1.88 \mathrm{mmol}\right)$, DIPEA (0.44 mL, $2.51 \mathrm{mmol})$ and benzylamine $(0.15 \mathrm{~mL}$, $1.38 \mathrm{mmol}$ ) were dissolved in anhydrous DMF $(3 \mathrm{~mL})$. The carboxylic acid, 1, (350 mg, $1.25 \mathrm{mmol}$ in $1 \mathrm{~mL}$ DMF) was added slowly and dropwise to the solution and the mixture stirred at $\mathrm{rt}$ for $22 \mathrm{~h}$ under an argon atmosphere. The solvent was removed under reduced pressure, water was added to the crude residue and the mixture extracted with EtOAc $(4 \times 20 \mathrm{~mL})$. The organic layers were combined and washed successively with water $(1 \times 20 \mathrm{~mL})$ and brine $(1 \times 20 \mathrm{~mL})$, dried over $\mathrm{MgSO}_{4}$ and the solvent removed under reduced pressure. The crude mixture was purified by flash column chromatography (silica, gradient elution starting from $10 \%$ EtOAc in hexane to $50 \%$ EtOAc in hexane) to give a yellow oil ( $284 \mathrm{mg}, 62 \%$ ). $R_{\mathrm{f}} 0.35$ (silica, $50 \%$ EtOAc in hexane); ${ }^{1} \mathrm{H}$ NMR $\left(295 \mathrm{~K}, 400 \mathrm{MHz}, \mathrm{CDCl}_{3}\right) \delta_{\mathrm{H}} 8.48$ $\left(1 \mathrm{H}, \mathrm{s}, \mathrm{py}-\mathrm{H}^{3}\right), 8.22(1 \mathrm{H}, \mathrm{s}, \mathrm{NH}), 7.91\left(1 \mathrm{H}, \mathrm{s}, \mathrm{py}-\mathrm{H}^{5}\right), 7.34-7.27$ 
(5H, m, Ph-H), $4.72\left(2 \mathrm{H}, \mathrm{s}, \mathrm{py}-\mathrm{CH}_{2}\right), 4.64\left(2 \mathrm{H}, \mathrm{d},{ }^{3} J 6, \mathrm{CH}_{2} \mathrm{Ph}\right)$; ${ }^{13} \mathrm{C}$ NMR (295 K, $\left.100 \mathrm{MHz}, \mathrm{CDCl}_{3}\right) \delta_{\mathrm{C}} 162.9$ (CONH), 159.7 $\left(\right.$ py-C $\left.\mathrm{C}^{6}\right), 149.2\left(\right.$ py-C $\left.{ }^{2}\right), 138.0\left(\mathrm{Ph}-\mathrm{C}^{\mathrm{i}}\right), 132.6\left(\mathrm{py}-\mathrm{C}^{5}\right), 130.8$ (py$\left.\mathrm{C}^{3}\right), 128.9\left(\mathrm{Ph}-\mathrm{C}^{m}\right), 128.0\left(\mathrm{Ph}-\mathrm{C}^{p}\right), 127.8\left(\mathrm{Ph}-\mathrm{C}^{o}\right), 107.9\left(\mathrm{py}^{2} \mathrm{C}^{4}\right)$, $64.3\left(\mathrm{py}-\underline{\mathrm{CH}}_{2}\right), 43.7\left(\mathrm{CH}_{2} \mathrm{Ph}\right) ; \mathrm{m} / z\left(\mathrm{HRMS}^{+}\right) 390.9893[\mathrm{M}+\mathrm{Na}]^{+}$ (C14H13N2O2NaI ${ }^{127}$ requires 390.9919$)$.

\section{$N$-Benzyl-6-(hydroxymethyl)-4-((4-methoxyphenyl)ethynyl)- picolinamide, 3}

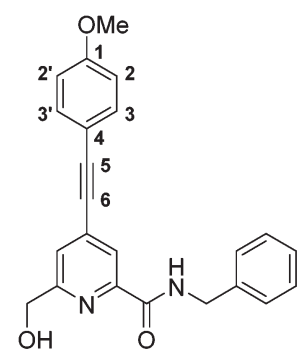

The alcohol, 2, (263 $\mathrm{mg}, 0.714 \mathrm{mmol}$ ) was dissolved in anhydrous THF ( $4 \mathrm{~mL}$ ) and the solution was degassed (freezethaw cycle) three times. 4-Ethynyl anisole $(140 \mu \mathrm{L}, 1.07 \mathrm{mmol})$ and triethylamine $(0.50 \mathrm{~mL}, 3.57 \mathrm{mmol})$ were added and the solution was degassed (freeze-thaw cycle) once more. [1,1-Bis(diphenylphosphino)ferrocene]dichloropalladium(II) (52 mg, $0.07 \mathrm{mmol}$ ) and $\mathrm{CuI}(27 \mathrm{mg}, 0.143 \mathrm{mmol}$ ) were added and the resulting brown solution was stirred at $65{ }^{\circ} \mathrm{C}$ under argon for $24 \mathrm{~h}$. The solvent was removed under reduced pressure and the pale brown solid was purified by column chromatography (silica, gradient elution starting from $100 \% \mathrm{CH}_{2} \mathrm{Cl}_{2}$ to $2 \%$ $\mathrm{CH}_{3} \mathrm{OH}$ in $\mathrm{CH}_{2} \mathrm{Cl}_{2}$ in $0.2 \%$ increments) to give an off white solid (210 mg, 80\%). $R_{\mathrm{f}} 0.75$ (silica, 7\% $\mathrm{CH}_{3} \mathrm{OH}$ in $\mathrm{CH}_{2} \mathrm{Cl}_{2}$ ); m.p. ${ }^{152-153}{ }^{\circ} \mathrm{C} ;{ }^{1} \mathrm{H}$ NMR $\left(295 \mathrm{~K}, 400 \mathrm{MHz}, \mathrm{CDCl}_{3}\right) \delta_{\mathrm{H}} 8.23$ $\left(1 \mathrm{H}\right.$, br t, $\left.{ }^{3} J 6, \mathrm{CON} \underline{\mathrm{H}}\right), 8.21\left(1 \mathrm{H}, \mathrm{s}, \mathrm{py}-\mathrm{H}^{3}\right), 7.53\left(1 \mathrm{H}, \mathrm{s}, \mathrm{py}-\mathrm{H}^{5}\right)$, $7.50\left(2 \mathrm{H}, \mathrm{dt},{ }^{4} J 2,{ }^{3} \mathrm{~J} 8, \mathrm{Ar}-\mathrm{H}^{3 / 3^{\prime}}\right), 7.37-7.34\left(4 \mathrm{H}, \mathrm{m}, \mathrm{Ph}-\mathrm{H}^{o}, \mathrm{Ph}-\right.$ $\left.\mathrm{H}^{m}\right), 7.29\left(1 \mathrm{H}, \mathrm{m}, \mathrm{Ph}-\mathrm{H}^{p}\right), 6.91\left(2 \mathrm{H}, \mathrm{dt},{ }^{4} J 2,{ }^{3} \mathrm{~J} 8, \mathrm{Ar}-\mathrm{H}^{2 / 2^{\prime}}\right), 4.77$ $\left(2 \mathrm{H}, \mathrm{s}, \mathrm{py}-\mathrm{CH}_{2}\right), 4.68\left(2 \mathrm{H}, \mathrm{d},{ }^{3} J 6, \mathrm{CH}_{2} \mathrm{Ph}\right), 3.85\left(3 \mathrm{H}, \mathrm{s}, \mathrm{OCH}_{3}\right)$; ${ }^{13} \mathrm{C} \mathrm{NMR}\left(295 \mathrm{~K}, 100 \mathrm{MHz}, \mathrm{CDCl}_{3}\right) \delta_{\mathrm{C}} 163.7(\mathrm{CONH}), 160.7(\mathrm{Ar}-$ $\left.\mathrm{C}^{1}\right), 158.7\left(\right.$ py-C $\left.\mathrm{C}^{6}\right), 149.2\left(\mathrm{py}-\mathrm{C}^{2}\right), 138.2\left(\mathrm{C}^{\mathrm{i}}\right), 134.6\left(\mathrm{Ar}-\mathrm{C}^{4}\right)$, 133.8 $\left(\mathrm{Ar}-\mathrm{C}^{3,3^{\prime}}\right), 128.9$ (Ph-C), 128.0 (Ph-C), 127.8 (Ph-C), 124.7 $\left(\right.$ py- $\left.\mathrm{C}^{5}\right), 123.5\left(\right.$ py- $\left.\mathrm{C}^{3}\right), 114.4\left(\mathrm{Ar}-\mathrm{C}^{2,2^{\prime}}\right), 114.0\left(\mathrm{py}-\mathrm{C}^{4}\right), 96.1$ $\left(\mathrm{C}^{5}\right), 85.6\left(\mathrm{C}^{6}\right), 64.6\left(\mathrm{py}-\underline{\mathrm{CH}}_{2}\right), 55.5\left(\mathrm{OCH}_{3}\right), 43.7\left(\underline{\mathrm{CH}}_{2} \mathrm{Ph}\right) ; \mathrm{m} / \mathrm{z}$ $\left(\mathrm{HRMS}^{+}\right) 373.1561[\mathrm{M}+\overline{\mathrm{H}}]^{+}\left(\mathrm{C}_{23} \mathrm{H}_{21} \mathrm{~N}_{2} \mathrm{O}_{3}\right.$ requires 373.1552$)$.

(6-(Benzylcarbamoyl)-4-((4-methoxyphenyl)ethynyl)pyridin2-yl)methyl methanesulfonate, 4

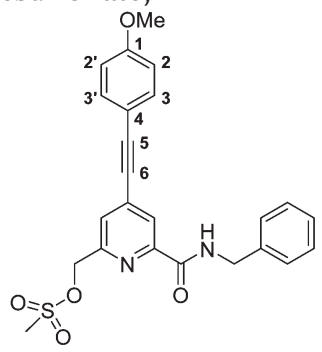

The alcohol, 3, (201 mg, $0.54 \mathrm{mmol}$ ) was dissolved in anhydrous THF $(4 \mathrm{~mL})$ and $\mathrm{NEt}_{3}(0.26 \mathrm{~mL}, 1.89 \mathrm{mmol})$ was added. The mixture was stirred at $5{ }^{\circ} \mathrm{C}$, methanesulfonyl chlor- ide $(0.06 \mathrm{~mL}, 0.81 \mathrm{mmol})$ was added and the reaction stirred at rt for 30 minutes and monitored by TLC. The solvent was removed under reduced pressure and the residue dissolved in $\mathrm{CH}_{2} \mathrm{Cl}_{2}(20 \mathrm{~mL})$ and washed with $\mathrm{NaCl}$ solution (saturated, $20 \mathrm{~mL})$. The aqueous layer was re-extracted with $\mathrm{CH}_{2} \mathrm{Cl}_{2}(3 \times$ $20 \mathrm{~mL}$ ) and the organic layers were combined, dried over $\mathrm{MgSO}_{4}$, filtered and the solvent removed under reduced pressure to yield a bright yellow oil (254 mg), which was used directly in the next step without further purification. $R_{\mathrm{f}} 0.72$ (silica, $100 \%$ EtOAc); ${ }^{1} \mathrm{H}$ NMR $\left(295 \mathrm{~K}, 700 \mathrm{MHz}, \mathrm{CDCl}_{3}\right) \delta_{\mathrm{H}} 8.27\left(1 \mathrm{H}, \mathrm{d},{ }^{3} J 1.5\right.$, py- $\left.\mathrm{H}^{5}\right), 8.26\left(1 \mathrm{H}, \mathrm{t},{ }^{3} J 6, \mathrm{CONH}\right), 7.63\left(1 \mathrm{H}, \mathrm{d},{ }^{3} J 1.5, \mathrm{py}-\mathrm{H}^{3}\right), 7.51$ $\left(2 \mathrm{H}, \mathrm{dt},{ }^{4} J\right.$ 2.5, ${ }^{3} J$ 9, Ar- $\left.\mathrm{H}^{3 / 3^{\prime}}\right), 7.37-7.29(5 \mathrm{H}, \mathrm{m}, \mathrm{Ph}-\mathrm{H}), 6.92$ $\left(2 \mathrm{H}, \mathrm{dt},{ }^{4} J 2.5,{ }^{3} J\right.$ 9, Ar- $\left.\mathrm{H}^{2 / 2}\right), 5.30\left(2 \mathrm{H}, \mathrm{s}, \mathrm{py}-\mathrm{CH}_{2}\right), 4.68(2 \mathrm{H}, \mathrm{d}$, ${ }^{3} J$ 6, $\left.\mathrm{CH}_{2} \mathrm{Ph}\right), 3.85\left(3 \mathrm{H}, \mathrm{s}, \mathrm{OCH}_{3}\right), 3.07\left(3 \mathrm{H}, \mathrm{s}, \mathrm{SO}_{2} \mathrm{CH}_{3}\right) ; \mathrm{m} / z$ $\left(\mathrm{HRMS}^{+}\right) 451.1320[\mathrm{M}+\mathrm{H}]^{+}\left(\mathrm{C}_{24} \mathrm{H}_{23} \mathrm{~N}_{2} \mathrm{O}_{5} \mathrm{~S}\right.$ requires 451.1328).

tert-Butyl-4,7-bis((6-(benzylcarbamoyl)-4-((4-methoxyphenyl)ethynyl)pyridin-2-yl)methyl)-1,4,7-triazacyclononane-1carboxylate, 5

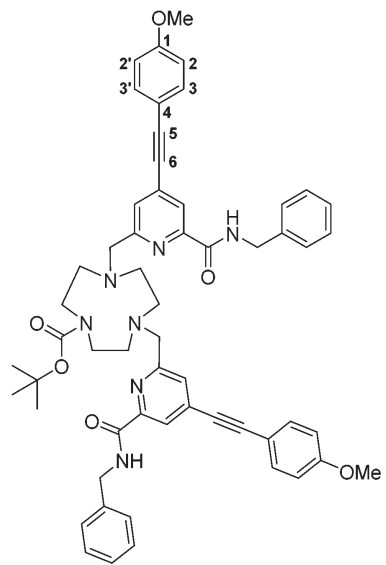

tert-Butyl-1,4,7-triazacyclononane-1-carboxylate dihydrochloride (82 $\mathrm{mg}, 0.27 \mathrm{mmol}$ ) and the mesylate, 4, (243 $\mathrm{mg}$, $0.54 \mathrm{mmol})$ were dissolved in anhydrous $\mathrm{CH}_{3} \mathrm{CN}(10 \mathrm{~mL})$ and $\mathrm{K}_{2} \mathrm{CO}_{3}$ (149 mg, $1.08 \mathrm{mmol}$ ) was added. The mixture was stirred under argon at $78^{\circ} \mathrm{C}$. After $24 \mathrm{~h}$ the reaction was cooled and filtered to remove excess potassium salts. The solvent was removed under reduced pressure and the crude material purified by column chromatography (silica, gradient elution starting from $100 \% \mathrm{CH}_{2} \mathrm{Cl}_{2}$ to $5 \% \mathrm{CH}_{3} \mathrm{OH}$ in $\mathrm{CH}_{2} \mathrm{Cl}_{2}$ in $0.2 \%$ increments) to give a pale yellow oil (170 mg, 67\%). $R_{\mathrm{f}} 0.39$ (silica, 5\% $\mathrm{CH}_{3} \mathrm{OH}$ in $\mathrm{CH}_{2} \mathrm{Cl}_{2}$ ); ${ }^{1} \mathrm{H} \mathrm{NMR}(295 \mathrm{~K}, 700 \mathrm{MHz}$, $\left.\mathrm{CDCl}_{3}\right) \delta_{\mathrm{H}} 8.44\left(1 \mathrm{H}, \mathrm{t},{ }^{3} J\right.$ 6.5, CONH$), 8.39\left(1 \mathrm{H}, \mathrm{t},{ }^{3} J 6.5\right.$, $\left.\mathrm{CONH}^{\prime}\right), 8.17\left(1 \mathrm{H}, \mathrm{s}, \mathrm{py}-\mathrm{H}^{5}\right), 8.16\left(1 \mathrm{H}, \mathrm{s}, \mathrm{py}-\mathrm{H}^{5^{\prime}}\right), 7.64(1 \mathrm{H}, \mathrm{s}$, py- $\left.\mathrm{H}^{3}\right), 7.57\left(1 \mathrm{H}, \mathrm{s}, \mathrm{py}-\mathrm{H}^{3^{\prime}}\right), 7.48\left(4 \mathrm{H}, \mathrm{d},{ }^{3} J\right.$ 9, $\left.\mathrm{Ar}-\mathrm{H}^{3 / 3^{\prime}}\right)$, 7.35-7.24 (10H, m, Ph-H), $6.89\left(4 \mathrm{H}, \mathrm{d},{ }^{3} J\right.$ 9, $\left.\mathrm{Ar}-\mathrm{H}^{2 / 2^{\prime}}\right), 4.65(4 \mathrm{H}$, d, ${ }^{3} J$ 6.5, $\left.\mathrm{C}_{2} \mathrm{Ph}\right), 3.83\left(6 \mathrm{H}, \mathrm{s}, \mathrm{OC}_{3}\right), 3.82\left(4 \mathrm{H}, \mathrm{s}, \mathrm{py}-\mathrm{C}_{2}\right)$, 3.31-3.26 $(4 \mathrm{H}, \mathrm{m}$, ring $H s), 3.05-2.96(4 \mathrm{H}, \mathrm{m}$, ring $H s)$, 2.68-2.62 (4H, m, ring $\mathrm{Hs}), 1.45\left(9 \mathrm{H}, \mathrm{s}, \mathrm{O}\left(\mathrm{CH}_{3}\right)_{3}\right) ;{ }^{13} \mathrm{C} \mathrm{NMR}$ $\left(295 \mathrm{~K}, 175 \mathrm{MHz}, \mathrm{CDCl}_{3}\right) \delta_{\mathrm{C}} 164.1(\mathrm{CONH}), 164.0(\mathrm{CONH})$, $160.6\left(\mathrm{Ar}-\mathrm{C}^{1}\right), 160.5\left(\mathrm{py}-\mathrm{C}^{2}\right), 159.3\left(\mathrm{py}-\mathrm{C}^{2^{\prime}}\right), 149.5\left(\mathrm{py}-\mathrm{C}^{6}\right)$, $149.3\left(\right.$ py- $\left.^{6^{\prime}}\right), 138.4\left(\mathrm{C}^{\mathrm{i}}\right), 138.3\left(\mathrm{C}^{\mathrm{i}}\right), 138.4\left(\mathrm{Ar}-\mathrm{C}^{4}\right), 138.3(\mathrm{Ar}-$ $\mathrm{C}^{3 / 3^{\prime}}$ ), 133.8 (Ph-C), 133.7 (Ph-C), 128.8 (Ph-C), 128.7 (Ph-C),

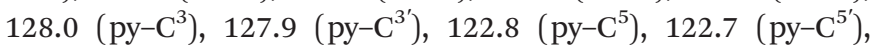
114.3 $\left(\mathrm{Ar}-\mathrm{C}^{2 / 2^{\prime}}\right), 114.1\left(\right.$ py- $\left.\mathrm{C}^{4}\right), 114.0\left(\right.$ py- $\left.\mathrm{C}^{4^{\prime}}\right), 95.4\left(\mathrm{C}^{5}\right), 95.1$ 
$\left(\mathrm{C}^{5^{\prime}}\right), 85.9\left(\mathrm{C}^{6}\right), 85.8\left(\mathrm{C}^{6^{\prime}}\right), 62.9\left(\mathrm{py}-\mathrm{CH}_{2}\right), 56.3$ (ring $\left.C\right), 55.4$ $\left(\mathrm{OCH}_{3}\right), 54.9$ (ring $C$ ), 54.5 (ring $C$ ), 53.9 (ring $C$ ), 50.1 (ring $C$ ), 49.6 (ring $C), 43.6\left(\underline{\mathrm{CH}}_{2} \mathrm{Ph}\right), 43.5\left(\mathrm{CH}_{2} \mathrm{Ph}\right), 28.7\left(\mathrm{O}\left(\underline{\mathrm{CH}}_{3}\right)_{3}\right) ; \mathrm{m} / z$ $\left(\mathrm{HRMS}^{+}\right) 938.4594[\mathrm{M}+\mathrm{H}]^{+}\left(\mathrm{C}_{57} \mathrm{H}_{60} \mathrm{~N}_{7} \mathrm{O}_{6}\right.$ requires 938.4605).

6,6'-((1,4,7-Triazacyclononane-1,4-diyl)bis(methylene))bis(N-benzyl-4-((4-methoxyphenyl)ethynyl)picolinamide), $\mathbf{L}^{2}$

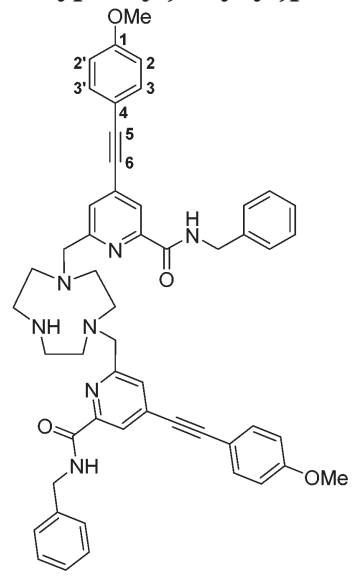

The BOC protected ligand, 5, (60 mg, $0.064 \mathrm{mmol})$ was dissolved in anhydrous $\mathrm{CH}_{2} \mathrm{Cl}_{2}(3 \mathrm{~mL})$ and trifluoroacetic acid $(0.6 \mathrm{~mL})$ was added. The solution was stirred under argon at $23{ }^{\circ} \mathrm{C}$ for $30 \mathrm{~min}$. TLC (silica; $10 \% \mathrm{CH}_{3} \mathrm{OH}$ in $\mathrm{CH}_{2} \mathrm{Cl}_{2}, R_{\mathrm{f}}$ (product) $=0.25, R_{\mathrm{f}}$ (reactant) $=0.61$ ) was used to confirm removal of the tert-butoxycarbonyl group. The solvent was removed under reduced pressure and the residue re-dissolved in $\mathrm{CH}_{2} \mathrm{Cl}_{2}(2 \mathrm{~mL})$. This process was repeated 5 times to ensure removal of excess trifluoroacetic acid. The crude residue was purified by preparative RP-HPLC (gradient: $30-100 \% \mathrm{CH}_{3} \mathrm{OH}$ $\left(0.1 \%\right.$ formic acid) in water $\left(0.1 \%\right.$ formic acid) over $18 \mathrm{~min} ; t_{\mathrm{R}}$ $14.6 \mathrm{~min}$ ) to afford a white solid (41 mg, 72\%). $R_{\mathrm{f}} 0.25$ (silica, $10 \% \mathrm{CH}_{3} \mathrm{OH}$ in $\left.\mathrm{CH}_{2} \mathrm{Cl}_{2}\right)$; m.p. $156-158{ }^{\circ} \mathrm{C} ;{ }^{1} \mathrm{H}$ NMR $(295 \mathrm{~K}$, $\left.700 \mathrm{MHz}, \mathrm{CDCl}_{3}\right) \delta_{\mathrm{H}} 7.92\left(2 \mathrm{H}, \mathrm{s}, \mathrm{py}-\mathrm{H}^{3}\right), 7.63\left(2 \mathrm{H}, \mathrm{s}, \mathrm{py}-\mathrm{H}^{5}\right)$, $7.38\left(4 \mathrm{H}, \mathrm{d},{ }^{3} J\right.$ 8.5, Ar- $\left.\mathrm{H}^{3 / 3^{\prime}}\right), 7.32-7.21(10 \mathrm{H}, \mathrm{m}, \mathrm{Ph}-\mathrm{H}), 6.91$ $\left(4 \mathrm{H}, \mathrm{d},{ }^{3} J\right.$ 8.5, $\left.\mathrm{Ar}-\mathrm{H}^{2 / 2}\right), 4.59\left(4 \mathrm{H}, \mathrm{s}, \mathrm{CH}_{2} \mathrm{Ph}\right), 3.95(4 \mathrm{H}, \mathrm{s}, \mathrm{py}-$ $\left.\mathrm{CH}_{2}\right), 3.78\left(6 \mathrm{H}, \mathrm{s}, \mathrm{OCH}_{3}\right), 3.06(4 \mathrm{H}, \mathrm{m}$, ring $\mathrm{Hs}), 2.93(4 \mathrm{H}, \mathrm{m}$, ring $H s), 2.74(4 \mathrm{H}, \mathrm{m}$, ring $H s) ;{ }^{13} \mathrm{C}$ NMR $(295 \mathrm{~K}, 175 \mathrm{MHz}$, $\left.\mathrm{CDCl}_{3}\right) \delta_{\mathrm{C}} 116.0(\mathrm{CONH}), 162.3\left(\mathrm{Ar}-\mathrm{C}^{1}\right), 159.9\left(\mathrm{py}-\mathrm{C}^{6}\right), 151.1$ $\left(\mathrm{py}-\mathrm{C}^{2}\right), 139.7\left(\mathrm{C}^{\mathrm{i}}\right), 135.4\left(\mathrm{Ar}-\mathrm{C}^{4}\right), 134.6\left(\mathrm{Ar}-\mathrm{C}^{3 / 3^{\prime}}\right), 129.7(\mathrm{Ph}-\mathrm{C})$, 128.7 (Ph-C), 128.5 (Ph-C), $128.0\left(\right.$ py- $\left.\mathrm{C}^{5}\right), 123.8$ (py-C $\left.{ }^{3}\right), 115.4$ $\left(\mathrm{Ar}-\mathrm{C}^{2 / 2^{\prime}}\right), 114.7\left(\mathrm{py}-\mathrm{C}^{4}\right), 96.8\left(\mathrm{C}^{5}\right), 86.0\left(\mathrm{C}^{6}\right), 61.5\left(\mathrm{py}-\underline{C H}_{2}\right)$, $55.9\left(\mathrm{OCH}_{3}\right), 51.6$ (ring $\left.C\right), 45.1$ (ring $\left.C\right), 44.3\left(\underline{\mathrm{CH}}_{2} \mathrm{Ph}\right) ; \mathrm{m} / \mathrm{z}$ $\left(\mathrm{HRMS}^{+}\right) 838.4083[\mathrm{M}+\mathrm{H}]^{+}\left(\mathrm{C}_{52} \mathrm{H}_{52} \mathrm{~N}_{7} \mathrm{O}_{4}\right.$ requires 838.4081).

\section{$\left[\mathrm{EuL}^{2}\right](\mathrm{OTf})_{3}$}

The deprotected ligand, $\mathbf{L}^{2}$, was subjected to ion exchange chromatography to remove any formate present (from HPLC purification). The ligand ( $4 \mathrm{mg}, 0.005 \mathrm{mmol}$ ) was dissolved in $\mathrm{CH}_{3} \mathrm{OH}$ and $\mathrm{Eu}(\mathrm{OTf})_{3}(3 \mathrm{mg}, 0.005 \mathrm{mmol})$ was added. The solution was stirred at $60^{\circ} \mathrm{C}$ for $24 \mathrm{~h}$ and the extent of the reaction was monitored by analytical HPLC (complex: RT $=10.57$, ligand $\mathrm{RT}=12.74 ; 10-100 \% \mathrm{CH}_{3} \mathrm{OH}(0.1 \%$ formic acid $): \mathrm{H}_{2} \mathrm{O}$ $(0.1 \%$ formic acid)). The solvent was removed under reduced pressure to give a white solid that was used directly without any further purification. LRMS (ESI MeCN) $m / z 1285$ $\left[\mathrm{M}+2\left(\mathrm{CF}_{3} \mathrm{SO}_{3}\right)\right]^{+}, 569\left[\mathrm{M}+\left(\mathrm{CF}_{3} \mathrm{SO}_{3}\right)\right]^{2+} \cdot \lambda_{\text {exc }}(\mathrm{MeOH})=348 \mathrm{~nm} ;$ $\phi(\mathrm{MeOH}) 0.02, \varepsilon(\mathrm{MeOH}) 40000 \mathrm{M}^{-1} \mathrm{~cm}^{-1} ; \tau\left(\mathrm{H}_{2} \mathrm{O}\right)=0.26 \mathrm{~ms}$, $\tau\left(\mathrm{D}_{2} \mathrm{O}\right)=0.43 \mathrm{~ms}, q=1.3$.

((4-Methoxy-2,6-dimethylphenyl)ethynyl)trimethylsilane<smiles>COc1cc(C)c(C#C[Si](C)(C)C)c(C)c1</smiles>

2-Iodo-5-methoxy-1,3-dimethylbenzene (1.34 g, $5.12 \mathrm{mmol}$ ) was dissolved in anhydrous THF $(13 \mathrm{~mL})$ and the solution was degassed (freeze-thaw cycle) three times. Ethynyl trimethylsilane $(2.18 \mathrm{~mL}, 15.4 \mathrm{mmol})$ and triethylamine $(3.57 \mathrm{~mL}$, $25.6 \mathrm{mmol}$ ) were added and the solution was degassed (freeze-thaw cycle) once more. [1,1-Bis(diphenylphosphino)ferrocene]dichloropalladium(II) (374 mg, $0.511 \mathrm{mmol}$ ) and $\mathrm{CuI}$ (195 mg, $1.02 \mathrm{mmol}$ ) were added and the resulting brown solution was stirred at $65{ }^{\circ} \mathrm{C}$ under argon for $24 \mathrm{~h}$. The solvent was removed under reduced pressure and the resulting brown oil was purified by column chromatography (silica, gradient elution starting from $100 \%$ hexane to $6 \% \mathrm{CH}_{2} \mathrm{Cl}_{2}$ in hexane in $0.2 \%$ increments) to afford a bright yellow oil (742 $\mathrm{mg}, 62 \%$ ). $R_{\mathrm{f}} 0.19$ (silica, $10 \% \mathrm{CH}_{2} \mathrm{Cl}_{2}$ in hexane); ${ }^{1} \mathrm{H}$ NMR $(295 \mathrm{~K}$, $\left.400 \mathrm{MHz}, \mathrm{CDCl}_{3}\right) \delta_{\mathrm{H}} 6.57(2 \mathrm{H}, \mathrm{s}, \mathrm{Ar}-\mathrm{H}), 3.77\left(3 \mathrm{H}, \mathrm{s}, \mathrm{OCH}_{3}\right)$, $2.41\left(6 \mathrm{H}, \mathrm{s}, \mathrm{CH}_{3}\right), 0.25\left(9 \mathrm{H}, \mathrm{s}, \mathrm{Si}\left(\mathrm{CH}_{3}\right)_{3}\right) ;{ }^{13} \mathrm{C} \mathrm{NMR}(295 \mathrm{~K}$, $\left.100 \mathrm{MHz}, \mathrm{CDCl}_{3}\right) \delta_{\mathrm{C}} 159.2\left(\mathrm{Ar}-\mathrm{C}^{1}\right), 142.6(\mathrm{Ar}-\mathrm{C}), 113.1(\mathrm{Ar}-\mathrm{C})$, 112.5 (Ar-C), 103.1 (alkyne C), 101.0 (alkyne C), $55.3\left(\mathrm{OCH}_{3}\right)$, $21.4\left(\underline{\mathrm{CH}}_{3}\right), 0.40\left(\mathrm{Si}\left(\underline{\mathrm{CH}}_{3}\right)_{3}\right) ; \mathrm{GC}-\mathrm{EI}, t_{\mathrm{R}}=4.47, \mathrm{~m} / \mathrm{z} 232\left(\mathrm{M}^{+}\right), 217$ $\left(\mathrm{M}^{+}-\mathrm{CH}_{3}\right)$.

2-Ethynyl-5-methoxy-1,3-dimethylbenzene, $6^{23}$<smiles>C#Cc1c(C)cc(OC)cc1C</smiles>

The silyl-protected alkyne (400 mg, $1.72 \mathrm{mmol}$ ) was dissolved in dry THF $(7 \mathrm{~mL})$ and triethylamine trihydrofluoride (2.80 $\mathrm{mL}, 17.2 \mathrm{mmol}$ ) was added. The solution was stirred at $40{ }^{\circ} \mathrm{C}$ under argon for $72 \mathrm{~h}$. The solvent was removed under reduced pressure and the crude residue was purified by flash column chromatography (silica, gradient elution starting from $100 \%$ hexane to $2 \% \mathrm{CH}_{2} \mathrm{Cl}_{2}$ in hexane in $0.2 \%$ increments) to give a pale yellow oil (154 mg, 56\%). $R_{\mathrm{f}} 0.19$ (silica, 10\% $\mathrm{CH}_{2} \mathrm{Cl}_{2}$ in hexane); ${ }^{1} \mathrm{H} \mathrm{NMR}\left(295 \mathrm{~K}, 400 \mathrm{MHz}, \mathrm{CDCl}_{3}\right) \delta_{\mathrm{H}} 6.60$ $(2 \mathrm{H}, \mathrm{s}, \mathrm{Ar}-\mathrm{H}), 3.79\left(3 \mathrm{H}, \mathrm{s}, \mathrm{OCH}_{3}\right), 3.43(1 \mathrm{H}, \mathrm{s}, \mathrm{ArCC} \underline{\mathrm{H}}), 2.44$ $\left(6 \mathrm{H}, \mathrm{s}, 2 \mathrm{CH}_{3}\right) ;{ }^{13} \mathrm{C} \mathrm{NMR}\left(295 \mathrm{~K}, 100 \mathrm{MHz}, \mathrm{CDCl}_{3}\right) \delta_{\mathrm{C}} 159.3(\mathrm{Ar}-$ $\mathrm{C}^{1}$ ), 142.8 (Ar-C), 144.4 (Ar-C), 112.5 (Ar-C), 83.9 (alkyne C), 81.4 (alkyne C), $55.3\left(\mathrm{OCH}_{3}\right), 21.4\left(2 \underline{\mathrm{CH}}_{3}\right) ; \mathrm{GC}-\mathrm{EI} t=3.75, \mathrm{~m} / z$ $160\left(\mathrm{M}^{+}\right), 145\left(\mathrm{M}^{+}-\mathrm{CH}_{3}\right)$. 
Methyl 6-(hydroxymethyl)-4-((4-methoxy-2,6-dimethylphenyl)ethynyl)picolinate, $7^{23}$

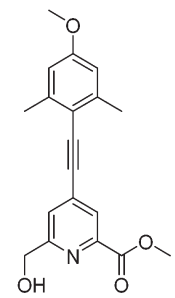

Methyl 6-(hydroxymethyl)-4-iodopicolinate, (243 mg, $0.829 \mathrm{mmol}$ ) was dissolved in anhydrous THF $(5 \mathrm{~mL})$ and the solution was degassed (freeze-pump-thaw cycle) three times. The alkyne, 2-ethynyl-5-methoxy-1,3-dimethylbenzene, (146 mg, $0.913 \mathrm{mmol}$ ) and triethylamine (0.58 mL, $4.14 \mathrm{mmol}$ ) were added and the solution was degassed (freeze-pumpthaw cycle) once more. [1,1-Bis(diphenylphosphino)ferrocene]dichloropalladium(II) (61 mg, $0.083 \mathrm{mmol}$ ) and CuI (32 mg, $0.168 \mathrm{mmol}$ ) were added and the resulting brown solution was stirred at $65^{\circ} \mathrm{C}$ under argon for $24 \mathrm{~h}$. The solvent was removed under reduced pressure and the resulting brown oil was purified by column chromatography (silica, gradient elution starting from $100 \%$ hexane to $70 \%$ EtOAc in hexane in $10 \%$ increments) to give a white solid (169 mg, 63\%). $R_{\mathrm{f}} 0.31$ (silica, $100 \%$ EtOAc); m.p. $177-179{ }^{\circ} \mathrm{C} ;{ }^{1} \mathrm{H}$ NMR $(295 \mathrm{~K}, 700 \mathrm{MHz}$, $\left.\mathrm{CDCl}_{3}\right) \delta_{\mathrm{H}} 8.05\left(1 \mathrm{H}, \mathrm{s}, \mathrm{py}-\mathrm{H}^{3}\right), 7.58\left(1 \mathrm{H}, \mathrm{s}, \mathrm{py}-\mathrm{H}^{5}\right), 6.63(2 \mathrm{H}, \mathrm{s}$, $\left.\mathrm{Ar}-\mathrm{H}^{2,2^{\prime}}\right), 4.86\left(2 \mathrm{H}, \mathrm{s}, \mathrm{py}-\mathrm{CH}_{2}\right), 4.01\left(3 \mathrm{H}, \mathrm{s}, \mathrm{CO}_{2} \mathrm{CH}_{3}\right), 3.80(3 \mathrm{H}$, $\left.\mathrm{s}, \mathrm{OCH}_{3}\right), 2.49\left(6 \mathrm{H}, \mathrm{s}, \mathrm{CH}_{3}\right) ;{ }^{13} \mathrm{C} \mathrm{NMR}\left(295 \mathrm{~K}, 175 \mathrm{MHz}, \mathrm{CDCl}_{3}\right)$ $\delta_{\mathrm{C}} 165.5\left(\mathrm{CO}_{2} \mathrm{CH}_{3}\right), 160.6\left(\mathrm{Ar}-\mathrm{C}^{1}\right), 160.2\left(\mathrm{py}-\mathrm{C}^{6}\right), 147.3\left(\mathrm{Ar}-\mathrm{C}^{4}\right)$, $143.1\left(\mathrm{py}^{-\mathrm{C}^{2}}\right), 134.4\left(\mathrm{Ar}-\mathrm{C}^{3,3^{\prime}}\right), 125.5\left(\mathrm{py}-\mathrm{C}^{3}\right), 125.2\left(\mathrm{py}^{2} \mathrm{C}^{5}\right)$, $114.0\left(\right.$ py- $\left.\mathrm{C}^{4}\right), 112.8\left(\mathrm{Ar}-\mathrm{C}^{2,2^{\prime}}\right), 94.0$ (alkyne $\mathrm{C}^{5}$ ), 93.3 (alkyne $\left.\mathrm{C}^{6}\right), 64.7\left(\mathrm{py}-\underline{\mathrm{CH}}{ }_{2}\right), 55.3\left(\mathrm{OCH}_{3}\right), 53.1\left(\mathrm{CO}_{2} \underline{\mathrm{CH}}_{3}\right), 21.5\left(\underline{\mathrm{CH}}_{3}\right)$; $\mathrm{m} / \mathrm{z}\left(\mathrm{HRMS}^{+}\right) \quad 326.1378[\overline{\mathrm{M}}+\mathrm{H}]^{+}\left(\mathrm{C}_{19} \overline{\mathrm{H}}_{20} \mathrm{NO}_{4}\right.$ requires 326.1392).

Methyl 4-((4-methoxy-2,6-dimethylphenyl)ethynyl)6-(((methylsulfonyl)oxy)methyl)picolinate, $8^{23}$<smiles>COC(=O)c1cc(C#Cc2c(C)cc(OC)cc2C)cc(COS(C)(=O)=O)n1</smiles>

The alcohol, 7, (89 mg, $0.274 \mathrm{mmol}$ ) was dissolved in anhydrous THF $(3 \mathrm{~mL})$ and $\mathrm{NEt}_{3}(0.13 \mathrm{~mL}, 0.959 \mathrm{mmol})$ was added. The mixture was stirred at $5{ }^{\circ} \mathrm{C}$, methanesulfonyl chloride $(30 \mu \mathrm{L}, 0.411 \mathrm{mmol})$ was added and the reaction stirred at rt for 30 minutes and monitored by TLC. The solvent was removed under reduced pressure and the residue dissolved in EtOAc $(15 \mathrm{~mL})$ and washed with $\mathrm{NaCl}$ solution (saturated, $15 \mathrm{~mL})$. The aqueous layer was re-extracted with EtOAc $(3 \times$ $15 \mathrm{~mL}$ ) and the organic layers were combined, dried over $\mathrm{MgSO}_{4}$, filtered and the solvent removed under reduced pressure to yield the mesylate, as a bright yellow oil (107 mg, $97 \%$ ), which was used directly in the next step without further purification. $R_{\mathrm{f}} 0.63$ (silica, 100\% EtOAc); ${ }^{1} \mathrm{H}$ NMR $(295 \mathrm{~K}$, $\left.400 \mathrm{MHz}, \mathrm{CDCl}_{3}\right) \delta_{\mathrm{H}} 8.06\left(1 \mathrm{H}, \mathrm{s}, \mathrm{py}-\mathrm{H}^{3}\right), 7.62\left(1 \mathrm{H}, \mathrm{s}, \mathrm{py}-\mathrm{H}^{5}\right)$, $6.58(2 \mathrm{H}, \mathrm{s}, \mathrm{Ar}-\mathrm{H}), 5.37\left(2 \mathrm{H}, \mathrm{s}, \mathrm{py}-\mathrm{CH}_{2} \mathrm{OSO}_{2}\right), 3.97(3 \mathrm{H}, \mathrm{s}$, $\left.\mathrm{CO}_{2} \mathrm{CH}_{3}\right), 3.75\left(3 \mathrm{H}, \mathrm{s}, \mathrm{OCH}_{3}\right), 3.14\left(3 \mathrm{H}, \mathrm{s}, \mathrm{SO}_{2} \mathrm{CH}_{3}\right), 2.44(6 \mathrm{H}, \mathrm{s}$, $\left.\mathrm{CH}_{3}\right) ; m / z\left(\mathrm{HRMS}^{+}\right) 404.1170[\mathrm{M}+\mathrm{H}]^{+}\left(\mathrm{C}_{20} \mathrm{H}_{22} \mathrm{NO}_{6} \mathrm{~S}\right.$ requires 404.1168).

\section{Dimethyl ester of $\mathbf{L}^{3}, 9$}

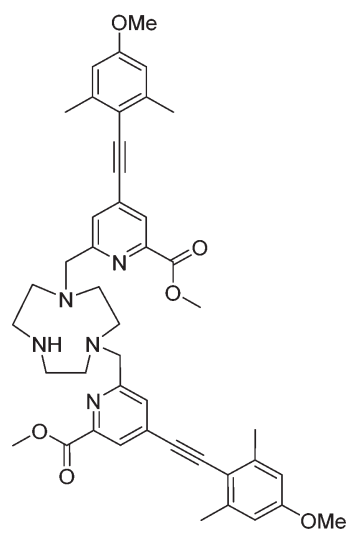

1,4,7-Triazacyclononane trihydrochloride (113 mg, $0.474 \mathrm{mmol}$ ) and the mesylate, 8, (363 $\mathrm{mg}, 0.901 \mathrm{mmol})$ were dissolved in anhydrous $\mathrm{CH}_{3} \mathrm{CN}(30 \mathrm{~mL})$ and $\mathrm{K}_{2} \mathrm{CO}_{3}(197 \mathrm{mg}, 1.42 \mathrm{mmol})$ was added. The mixture was stirred under argon at $60{ }^{\circ} \mathrm{C}$ and monitored by LC-MS. After $1 \mathrm{~h}$ the reaction was cooled and filtered to remove excess potassium salts. The solvent was removed under reduced pressure and the crude material purified by column chromatography (silica, gradient elution starting from $100 \% \mathrm{CH}_{2} \mathrm{Cl}_{2}$ to $10 \% \mathrm{CH}_{3} \mathrm{OH}$ in $\mathrm{CH}_{2} \mathrm{Cl}_{2}$ in $1 \%$ increments) to give a yellow glassy solid (183 mg, $52 \%) . R_{\mathrm{f}} 0.18$ (silica, $10 \% \mathrm{CH}_{3} \mathrm{OH}$ in $\mathrm{CH}_{2} \mathrm{Cl}_{2}$ ); ${ }^{1} \mathrm{H}$ NMR (295 K, $700 \mathrm{MHz}$, $\left.\mathrm{CDCl}_{3}\right) \delta_{\mathrm{H}} 9.48(1 \mathrm{H}$, br s, ring $\mathrm{NH}), 7.91\left(2 \mathrm{H}, \mathrm{s}, \mathrm{py}-\mathrm{H}^{3}\right), 7.43$ $\left(2 \mathrm{H}, \mathrm{s}, \mathrm{py}-\mathrm{H}^{5}\right), 6.59(4 \mathrm{H}, \mathrm{s}, \mathrm{Ar}-\mathrm{H}), 4.03\left(6 \mathrm{H}, \mathrm{s}, \mathrm{CO}_{2} \mathrm{CH}_{3}\right), 4.02$ $\left(4 \mathrm{H}, \mathrm{s}, \mathrm{py}-\mathrm{CH}_{2}\right), 3.74\left(6 \mathrm{H}, \mathrm{s}, \mathrm{OCH}_{3}\right), 3.48(4 \mathrm{H}$, br s, ring $\mathrm{Hs})$, $3.06(4 \mathrm{H}$, br s, ring $\mathrm{Hs}), 2.81(4 \mathrm{H}$, s, ring $\mathrm{Hs}), 2.42\left(12 \mathrm{H}, \mathrm{s}, \mathrm{CH}_{3}\right)$; ${ }^{13} \mathrm{C} \mathrm{NMR}\left(295 \mathrm{~K}, 175 \mathrm{MHz}, \mathrm{CDCl}_{3}\right) \delta_{\mathrm{C}} 165.2\left(\mathrm{CO}_{2} \mathrm{CH}_{3}\right), 160.2$ $\left(\mathrm{Ar}-\mathrm{C}^{1}\right), 159.4\left(\mathrm{py}-\mathrm{C}^{6}\right), 147.6\left(\mathrm{Ar}-\mathrm{C}^{4}\right), 134.5\left(\mathrm{Ar}-\mathrm{C}^{3,3^{\prime}}\right), 126.9$ $\left(\right.$ py- $\left.\mathrm{C}^{5}\right), 125.7\left(\mathrm{py}-\mathrm{C}^{3}\right), 113.8\left(\mathrm{py}-\mathrm{C}^{4}\right), 112.8\left(\mathrm{Ar}-\mathrm{C}^{2,2^{\prime}}\right), 94.2$ (alkyne $\mathrm{C}^{5}$ ), $92.8\left(\right.$ alkyne $\left.\mathrm{C}^{6}\right), 60.3\left(\mathrm{py}^{-} \mathrm{CH}_{2}\right), 55.3\left(\mathrm{OCH}_{3}\right), 53.9$ (ring Cs), $53.6\left(\mathrm{CO}_{2} \underline{\mathrm{CH}}_{3}\right), 50.5$ (ring Cs), 46.2 (ring Cs), 21.4 $\left(\mathrm{CH}_{3}\right) ; m / z\left(\mathrm{HRMS}^{+}\right) 744.3765[\mathrm{M}+\mathrm{H}]^{+}\left(\mathrm{C}_{44} \mathrm{H}_{50} \mathrm{~N}_{5} \mathrm{O}_{6}\right.$ requires 744.3761).

\section{$\left[\mathrm{EuL}^{3}\right] \mathrm{Cl}$}

An aqueous solution of sodium hydroxide $0.1 \mathrm{M}(0.5 \mathrm{~mL})$ was added to a solution of the ester $\mathbf{9},(10 \mathrm{mg}, 13.4 \mu \mathrm{mol})$ in aqueous methanol $(1: 1,1 \mathrm{~mL})$. The mixture was stirred at $65{ }^{\circ} \mathrm{C}$ for $4 \mathrm{~h}$. The reaction was monitored by LCMS. Upon completion, aqueous hydrochloric acid $(0.1 \mathrm{M})$ was added until pH 6.5 was achieved. Europium chloride hexahydrate (5.4 mg, $14.7 \mu \mathrm{mol}$ ) was added and the $\mathrm{pH}$ was readjusted to 6.5 by addition of aqueous sodium hydroxide $(0.1 \mathrm{M})$. The reaction was stirred at $65{ }^{\circ} \mathrm{C}$ for $24 \mathrm{~h}$. The solvent was removed 
under reduced pressure to give a white solid ( $5 \mathrm{mg}, 43 \%$ ); $\mathrm{m} / \mathrm{z}$ $\left(\mathrm{HRMS}^{+}\right)$864.2371 $\mathrm{M}^{+}\left(\mathrm{C}_{42} \mathrm{H}_{43} \mathrm{~N}_{5} \mathrm{O}_{6}{ }^{151} \mathrm{Eu}\right.$ requires 864.2412); $\lambda_{\text {exc }}(\mathrm{MeOH})=352 \mathrm{~nm} ; \phi(\mathrm{MeOH}) 0.2, \varepsilon(\mathrm{MeOH}) 35000 \mathrm{M}^{-1}$ $\mathrm{cm}^{-1} ; \tau\left(\mathrm{H}_{2} \mathrm{O}\right)=0.27 \mathrm{~ms}, \tau\left(\mathrm{D}_{2} \mathrm{O}\right)=0.38 \mathrm{~ms}, q=0.9$.

\section{Dimethyl ester of $\mathrm{L}^{4}, 10$}

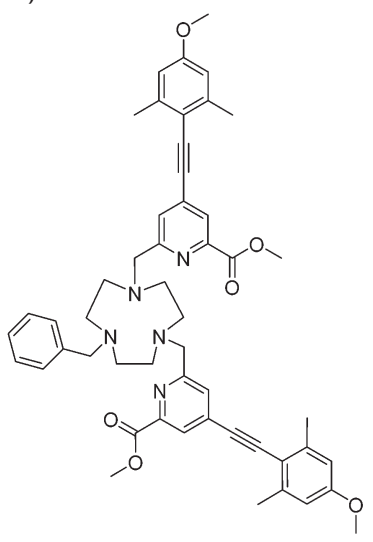

The bis-alkylated ligand, 9, (25 mg, $0.034 \mathrm{mmol}$ ) and $\mathrm{K}_{2} \mathrm{CO}_{3}$ (4 mg, $0.034 \mathrm{mmol}$ ) were dissolved in anhydrous $\mathrm{CH}_{3} \mathrm{CN}$ ( $2 \mathrm{~mL}$ ). Benzyl bromide (6 $\mathrm{mg}, 0.034 \mathrm{mmol}$ ) was added dropwise at room temperature over 15 minutes. The mixture was stirred under argon at $40{ }^{\circ} \mathrm{C}$ and monitored by LC-MS. After $3 \mathrm{~h}$ the reaction was cooled and filtered to remove excess potassium salts. The solvent was removed under reduced pressure and the crude material purified by column chromatography (alumina, $100 \% \mathrm{CH}_{2} \mathrm{Cl}_{2}$ ) to give a yellow glassy solid $(17 \mathrm{mg}$, $60 \%$ ). TLC analysis $R_{\mathrm{f}} 0.52$ (alumina, $2 \% \mathrm{CH}_{3} \mathrm{OH}$ in $\mathrm{CH}_{2} \mathrm{Cl}_{2}$ ); ${ }^{1} \mathrm{H}$ NMR (295 K, $\left.700 \mathrm{MHz}, \mathrm{MeOD}\right) \delta_{\mathrm{H}} 7.95\left(2 \mathrm{H}, \mathrm{s}, \mathrm{py}-\mathrm{H}^{3}\right)$, 7.58-7.43 (7H, m, Ph-H, py- $\left.\mathrm{H}^{5}\right), 6.64(4 \mathrm{H}, \mathrm{s}, \mathrm{Ar}-\mathrm{H}), 3.99(4 \mathrm{H}, \mathrm{s}$, py- $\left.\mathrm{CH}_{2}\right), 3.92\left(6 \mathrm{H}, \mathrm{s}, \mathrm{CO}_{2} \mathrm{CH}_{3}\right), 3.78\left(6 \mathrm{H}, \mathrm{s}, \mathrm{OCH}_{3}\right), 3.66(4 \mathrm{H}, \mathrm{br}$ s, ring $H s), 3.05(8 \mathrm{H}$, br s, ring $H s), 2.91\left(2 \mathrm{H}, \mathrm{s}, \mathrm{CH}_{2} \mathrm{Ph}\right), 2.42$ $\left(12 \mathrm{H}, \mathrm{s}, \mathrm{CH}_{3}\right) ;{ }^{13} \mathrm{C} \mathrm{NMR}\left(295 \mathrm{~K}, 175 \mathrm{MHz}, \mathrm{CDCl}_{3}\right) \delta_{\mathrm{C}} 165.7$ $\left(\mathrm{CO}_{2} \mathrm{CH}_{3}\right), 160.2\left(\mathrm{Ar}-\mathrm{C}^{1}\right), 147.6\left(\mathrm{py}-\mathrm{C}^{6}\right), 143.0\left(\mathrm{Ar}-\mathrm{C}^{4}\right), 133.9$ $\left(\mathrm{Ar}-\mathrm{C}^{3 / 3^{\prime}}\right), 129.1$ (Ph-C), 128.4 (Ph-C), 127.8 (Ph-C), 126.9 (py$\left.\mathrm{C}^{5}\right), 125.1\left(\mathrm{py}-\mathrm{C}^{3}\right), 114.1\left(\mathrm{py}-\mathrm{C}^{4}\right), 112.8\left(\mathrm{Ar}-\mathrm{C}^{2 / 2}\right), 93.6$ (alkyne C), $64.7\left(\right.$ py- $\left.\underline{\mathrm{CH}}_{2}\right), 56.3\left(\mathrm{Ph}-\underline{\mathrm{CH}}_{2}\right), 55.4\left(\mathrm{O}^{\mathrm{CH}}{ }_{3}\right), 53.1\left(\mathrm{CO}_{2} \underline{\mathrm{CH}}_{3}\right)$, 51.8 (ring Cs), 29.8 (ring Cs), $21.5\left(\underline{\mathrm{CH}}_{3}\right) ; \mathrm{m} / z\left(\mathrm{HRMS}^{+}\right) 834.4246$ $[\mathrm{M}+\mathrm{H}]^{+}\left(\mathrm{C}_{51} \mathrm{H}_{56} \mathrm{~N}_{5} \mathrm{O}_{6}\right.$ requires 834.4231).

\section{$\left[\mathrm{EuL}^{4}\right] \mathrm{Cl}$}

An aqueous solution of sodium hydroxide $0.1 \mathrm{M}(0.5 \mathrm{~mL})$ was added to a solution of $10(11 \mathrm{mg}, 13.2 \mu \mathrm{mol})$ in methanol $(1: 1,1 \mathrm{~mL})$. The mixture was stirred at $65^{\circ} \mathrm{C}$ for $4 \mathrm{~h}$. The reaction was monitored by LCMS. Upon completion, aqueous hydrochloric acid $(0.1 \mathrm{M})$ was added until pH 6.5 was achieved. Europium chloride hexahydrate $(5.3 \mathrm{mg}, 14.5 \mu \mathrm{mol})$ was added and the $\mathrm{pH}$ was readjusted to 6.5 by addition of aqueous sodium hydroxide $(0.1 \mathrm{M})$. The reaction was stirred at $65^{\circ} \mathrm{C}$ for $24 \mathrm{~h}$. The solvent was removed under reduced pressure and the solid was purified by flash column chromatography (silica, gradient elution starting from $5 \% \mathrm{CH}_{3} \mathrm{OH}$ to $15 \% \mathrm{CH}_{3} \mathrm{OH}$ in $\mathrm{CH}_{2} \mathrm{Cl}_{2}$ in $0.5 \%$ increments) to give a white solid (10 mg, 80\%). $\mathrm{m} / \mathrm{z}\left(\mathrm{HRMS}^{+}\right) 954.2896 \mathrm{M}^{+}\left(\mathrm{C}_{49} \mathrm{H}_{49} \mathrm{~N}_{5} \mathrm{O}_{6}{ }^{151} \mathrm{Eu}\right.$ requires 954.2881); $\lambda_{\text {exc }}(\mathrm{MeOH})=352 \mathrm{~nm} ; \phi(\mathrm{MeOH}) 0.18, \varepsilon(\mathrm{MeOH})$
$36000 \mathrm{M}^{-1} \mathrm{~cm}^{-1} ; \tau(\mathrm{MeOH})=0.83 \mathrm{~ms} ; \tau\left(\mathrm{H}_{2} \mathrm{O}\right)=0.53 \mathrm{~ms}$, $\tau\left(\mathrm{D}_{2} \mathrm{O}\right)=0.50 \mathrm{~ms}, q=0$.

\section{Acknowledgements}

We thank EPSRC, the Royal Society (RP) and the ERC (FCC266804) for support.

\section{Notes and references}

1 G. Muller, Dalton Trans., 2009, 9692.

2 (a) Z. Shen, T. Wang, L. Shi, Z. Tang and M. Liu, Chem. Sci., 2015, 6, 4267; (b) Y. Morisaki, M. Gon, T. Sasamori, N. Tokitoh and Y. Chujo, J. Am. Chem. Soc., 2014, 136, 3250.

3 R. Carr, N. H. Evans and D. Parker, Chem. Soc. Rev., 2012, 41, 7673.

4 F. Zinna and L. Di Bari, Chirality, 2015, 27, 1.

5 J.-C. G. Bunzli and S. V. Eliseeva, Chem. Sci., 2013, 4, 1939.

6 J. M. Zwier, H. Bazin, L. Lamarque and G. Mathis, Inorg. Chem., 2014, 53, 1854.

7 F. Kielar, C. P. Montgomery, E. J. New, D. Parker, R. A. Poole, S. L. Richardson and P. A. Stenson, Org. Biomol. Chem., 2007, 5, 2975.

8 (a) K. Okutani, K. Nozaki and M. Iwamura, Inorg. Chem., 2014, 53, 5527; (b) M. Iwamura, Y. Kimura, R. Miyamoto and K. Nozaki, Inorg. Chem., 2012, 51, 4094.

9 C. M. G. dos Santos, A. J. Harte and T. Gunnlaugsson, Coord. Chem. Rev., 2008, 252, 2512.

10 (a) S. J. Butler and D. Parker, Chem. Soc. Rev., 2013, 42, 1652; (b) G.-L. Law, D. Parker, S. L. Richardson and K.-L. Wong, Dalton Trans., 2009, 8481.

11 L. M. P. Lima and R. Tripier, Curr. Methods Inorg. Chem., 2011, 1, 36.

12 A. M. Funk, K.-L. N. A. Finney, P. Harvey, A. M. Kenwright, E. R. Neil, N. J. Rogers, P. K. Senanayake and D. Parker, Chem. Sci., 2015, 6, 1655.

13 A. M. Funk, P. Harvey, K.-L. N. A. Finney, M. A. Fox, A. M. Kenwright, N. J. Rogers and D. Parker, Phys. Chem. Chem. Phys., 2015, 17, 16507.

14 S. F. Mason, R. D. Peacock and B. Stewart, Mol. Phys., 1975, 30, 1829.

15 (a) S. F. Mason, Struct. Bonding, 1980, 39, 43; (b) M. F. Reid and F. S. Richardson, Chem. Phys. Lett., 1983, 95, 5012.

16 R. S. Dickins, J. I. Bruce, D. Parker and D. J. Tozer, Dalton Trans., 2003, 1264.

17 R. Pal, L. C. Costello and D. Parker, Org. Biomol. Chem., 2009, 7, 1525.

18 D. G. Smith, G.-L. Law, R. Pal, D. Parker and K.-L. Wong, Chem. Commun., 2011, 47, 7347.

19 D. G. Smith, R. Pal and D. Parker, Chem. - Eur. J., 2012, 18, 11604.

20 R. Pal, A. Beeby and D. Parker, J. Pharmaceut. Biomed. Anal., 2011, 56, 352. 
21 R. Carr, L. Di Bari, S. Lo Piano, D. Parker, R. D. Peacock and J. M. Sanderson, Dalton Trans., 2012, 41, 13154.

22 R. Carr, R. S. Puckrin, R. Pal, D. Parker, B. K. McMahon and L.-O. Palsson, Methods Appl. Fluoresc., 2014, 2, 024007.

23 M. Soulie, F. Latzko, E. Bourrier, V. Placide, S. J. Butler, R. Pal, P. L. Baldeck, B. Le Guennic, C. Andraud, J. M. Zwier, L. Lamarque, D. Parker and O. Maury, Chem. Eur. J., 2014, 20, 8636-8646.

24 S. J. Butler, L. Lamarque, R. Pal and D. Parker, Chem. Sci., 2014, 5, 1750.

25 J. W. Walton, A. Bourdolle, S. J. Butler, M. Soulie, M. Delbianco, B. K. McMahon, R. Pal, H. Puschmann, J. M. Zwier, L. Lamarque, O. Maury, C. Andraud and D. Parker, Chem. Commun., 2013, 49, 1600.

26 (a) S. J. Butler, M. Delbianco, N. H. Evans, A. T. Frawley, R. Pal, D. Parker, R. S. Puckrin and D. S. Yufit, Dalton Trans., 2014, 43, 5721; (b) N. H. Evans, R. Carr, M. Delbianco, R. Pal, D. S. Yufit and D. Parker, Dalton Trans., 2013, 42, 15610.

27 (a) M. Delbianco, V. Sadovnikova, E. Bourrier, L. Lamarque, J. M. Zwier and D. Parker, Angew. Chem., Int. Ed., 2014, 53, 10718; (b) M. Delbianco, L. Lamarque and D. Parker, Org. Biomol. Chem., 2014, 12, 8061.

28 S. J. Butler, R. Pal, B. K. McMahon, D. Parker and J. W. Walton, Chem. - Eur. J., 2013, 19, 9511.
29 R. S. Dickins, S. Aime, A. S. Batsanov, A. Beeby, M. Botta, J. I. Bruce, J. A. K. Howard, C. S. Love, D. Parker, R. D. Peacock and H. Puschmann, J. Am. Chem. Soc., 2002, 124, 12697.

30 R. S. Dickins, A. S. Batsanov, D. Parker, H. Puschmann, S. Salamano and J. A. K. Howard, Dalton Trans., 2004, 70.

31 A. Bourdolle, M. Allali, J.-C. Mulatier, B. Le Guennic, J. M. Zwier, P. L. Baldeck, J.-C. G. Bunzli, C. Andraud, L. Lamarque and O. Maury, Inorg. Chem., 2011, 50, 4987.

32 A. Beeby, I. M. Clarkson, R. S. Dickins, S. Faulkner, D. Parker, L. Royle, A. S. de Sousa, J. A. G. Williams and M. Woods, J. Chem. Soc., Perkin Trans. 2, 1999, 493.

33 P. L. Anelli, V. Balzani, L. Prodi and F. Uggeri, Gazz. Chim. Ital., 1991, 121, 359.

34 E. R. Neil, A. M. Funk, D. S. Yufit and D. Parker, Dalton Trans., 2014, 43, 5490.

35 T. T. da Cunha, J. Jung, M.-E. Boulon, G. Campo, F. Pointillart, C. L. M. Pereira, B. Le Guennic, O. Cador, K. Bernot, F. Pineider, S. Golhen and L. Ouahab, J. Am. Chem. Soc., 2013, 135, 16332.

36 K. Senechal-David, A. Hemeryck, N. Tancrez, L. Toupet, J. A. G. Williams, I. Ledoux, J. Zyss, A. Boucekkine, J.-P. Guegan, H. Le Bozec and O. Maury, J. Am. Chem. Soc., 2006, 128, 12243.

37 F. Pointillart, B. Le Guennic, O. Maury, S. Golhen, O. Cador and L. Ouahab, Inorg. Chem., 2013, 52, 1398. 